\title{
The Handover in Hong Kong: Impact on Business Formation
}

\author{
Glenn R. Carroll, ${ }^{\text {a Mi Feng, }{ }^{\mathrm{b}} \text { Jeroen G. Kuilmanc }}$
}

a) Stanford University; b) Peking University; c) Tilburg University

\begin{abstract}
Although the 1997 handover of Hong Kong from the United Kingdom to China was a major political transformation, its impact on new business formation has not been fully scrutinized. Theory suggests contradictory forces may operate before, during, and after such a transformation: either a decline due to uncertainty or an increase due to opportunities created. To determine which force dominated, we first decomposed the analysis by the size of major affected social groups, then analyzed the expected impact. This led us to predict an aggregate depression of business formation, although this effect likely showed great variation and attenuated over time. Our empirical assessment relied on detailed monthly records of business registrations from 1975 to 2013, using GARCH time series modeling to analyze total registrations as well as the proportions for local and non-local businesses. Controlling for macro socioeconomic conditions, we find the registration rate dropped significantly throughout the post-handover era, implying a dominance of uncertainty. Further, new registrations displayed higher volatility following the 1984 announcement of the handover, reflecting shifting public sentiment in the interim about Hong Kong's economic prospects. We also find a post-handover preference for forming non-local firms with higher asset mobility; this preference diminishes with time.
\end{abstract}

Keywords: Hong Kong handover; political transformation; business foundings

Editor(s): Olav Sorenson; Received: January 13, 2014; Accepted: May 2, 2014; Published: September 15, 2014

Citation: Carroll, Glenn R., Mi Feng, and Jeroen G. Kuilman 2014. "The Handover in Hong Kong: Impact on Business Formation." Sociological Science 1: 366-396. DOI: $10.15195 / \mathrm{v} 1 . \mathrm{a} 22$

Copyright: (C) 2014 Carroll, Feng, and Kuilman. This open-access article has been published and distributed under a Creative Commons Attribution License, which allows unrestricted use, distribution and reproduction, in any form, as long as the original author and source have been credited. ()(i)

7 HE 1997 handover of Hong Kong from the 1 United Kingdom to the People's Republic of China (PRC) stands as one of the major political transformations of the twentieth century. After 150 years of British rule, the handover ceded sovereignty of a territory of 426 square miles, 6.4 million persons, and an economy of $\mathrm{HK} \$ 1,218$ billion to the formally socialist Chinese government. The transfer took place within the structure of the Basic Law governing the Hong Kong Special Administrative Region, which promised in Article 5 that, "The socialist system and policies shall not be practiced in the Hong Kong Special Administrative Region, and the previous capitalist system and way of life shall remain unchanged, for 50 years."

Since the handover, Hong Kong has been scrutinized from many corners - from political activists, to journalists, to economists, to diplomats, to its neighbors and statist competitors. Almost everyone, it seems, wants to know what happened in Hong Kong and how the handover has changed social and economic life in the terri- tory (Ash et al. 2003). This was especially true in 2007 and 2012, dates that marked a decade and a decade and a half, respectively, of living under the vague autonomy signified by the Chinese dictum, "one nation, two systems.' 1

Despite many informative inquiries about Hong Kong's post-handover experiences, little empirical research has systematically examined the impact of the political transformation on business dynamics, and none has investigated its impact on the formation and operation of new businesses in the territory. Because the vitality of a capitalist system depends heavily on its underlying organizational infrastructure and the associated dynamics (Stark 1996; Grabher and Stark 1997), filling this gap promises to enhance our understanding of Hong Kong's transformation. Moreover, pre-handover Hong Kong frequently ranked as among the freest economies of the world in terms of ease of starting a business and lack of governmental interference. In short,

\footnotetext{
${ }^{1}$ As Hung and Kuo (2010) document, the origins of the principle date to earlier phases of Chinese history.
} 
Hong Kong's pre-handover economy allowed for relatively unfettered, fast access to markets - a state of affairs that showed in routinely high numbers of business registrations. Therefore, an important empirical question asks whether this activity has abated, persisted, or amplified after the handover; it also seems worthwhile to know if the composition of new business has shifted. In general, we suggest that any change in the organizational infrastructure of Hong Kong hints at the possibility of subsequent long-term economic and social changes lurking ahead.

Among major political transformations, the Hong Kong handover was unusual in its predetermination and relative predictability. The nineteenth century treaties that granted control of the territory to the British contained clauses that ceded sovereignty back to the Chinese at certain dates, which the Chinese insisted be honored. As these dates approached, pressure mounted to make the transition orderly, and in 1984 the two countries signed the Sino-British agreement, which set July 1, 1997, as the official handover date. China and Britain engaged in plenty of political jostling over the terms of the handover in the interim, and anxiety over the impending transformation reached almost shrill levels at times, despite the ratification of the Basic Law in 1990. However, there seemed little uncertainty about whether and when the transformation would actually occur-virtually no one doubted it would happen. Yet plenty of uncertainty existed over how the Chinese government would act and what impact its actions would effect, and views about these issues shifted over time. Raynor (1990) summarized the magnitude of the situation as he saw it contemporaneously:

The proposed transformation periodnearly 12 years - is one of the longest in the history of decolonization 2 It is the first capitalist territory to be handed over to communist rule, and, again for the first time, a Third World country - China - will be taking over a highly developed state: Hong Kong. There are no relevant precedents to draw upon.

\footnotetext{
${ }^{2} \mathrm{He}$ defines the transformation period rather narrowly as the pre-handover period.
}

Importantly, the preannounced handover date meant that effects of the transformation possibly started exerting themselves long before the actual transition, as various interests positioned themselves for what they expected might happen.

In this regard, the Hong Kong handover potentially contains interesting insight about how political environments affect organizational populations. Most political transformations of comparable scale were unexpected - or at least unpredictable in their timing. As a result, analysts usually associate periods of political transformation with uncertainty, and political transformation is often regarded anxiously as detrimental to business. Uncertainty involves many factors, including growth prospects, rules of trade, contract law, labor rights, and the like. At the core of such uncertainty for entrepreneurs is concern about the stability of property rights broadly defined and consequent worries about recovering anticipated future returns on investment (Jones 1981; Delong and Schleifer 1993; Olson 2000; Acemoglu and Robinson 2012). However, a different analytical view looks beyond any shortterm, transformation-induced turmoil and examines congruence between the new polity and the new organizational actors that may emerge. It focuses on the opportunities unleashed and reshuffled by the changed political system (Stinchcombe 1965; Fier 1998). Depending on the institutions, policies, interests, and actors that are reassembled, reconfigured, or replaced in a transformation, we imagine that processes involving either uncertainty or opportunity might dominate the organizational landscape.

As a result, we first juxtapose certain historical facts of the Hong Kong transformation with general theoretical ideas about uncertainty and opportunity. This exercise allows us to fashion falsifiable arguments about how the handover may have affected business formation - as indicated by the number of new business registrationsin Hong Kong. The arguments we develop draw from received theory and prior empirical enquiries (Stinchcombe 1965; Fier and Woywode 1994; Spenner et al., 1998; Dobrev 1999; Dobrev 2000; Dobrev 2001; Ingram and Simons 2000; Simons and Ingram 2003; Windzio 2003). Accordingly, the research strategy is neither entirely deductive nor fully designed around theory testing per se. 
Rather, the approach we use is perhaps more akin to retroduction, the inductive inference of hypotheses or propositions from data. This approach involves making empirical generalizations using information from the data themselves. According to Simon (1968), "in the history of science, the retroduction of generalization and explanations for data has been one of the central and crucial processes."

Nonetheless, the arguments we advance do extend theory about political transformation (Stinchcombe 1965; Fier and Woywode 1994; Spenner et al. 1998; Dobrev 1999; 2000; 2001; Ingram and Simons 2000; Simons and Ingram, 2003; Windzio 2003) in three novel ways. First, we address likely entrepreneurial activity in the build-up to the transformation as well as that occurring subsequently, whereas previous research concentrates on the aftermath. Second, we distinguish between anticipated effects on the temporal variance in business registration as well as on the more conventional mean level of registrations. Third, we consider the mobility of organizational assets in the transformation period and its aftermath, an understudied mechanism.

A primary goal of our efforts here is empiricaldiscovering and documenting exactly what happened in Hong Kong in the period of the handover. In the empirical analysis, we aim to address the gap in understanding exactly what happened to entrepreneurial business activity in Hong Kong before, during, and after the handover. Using official monthly business registration data, we analyze the rates of new business registration in Hong Kong from 1975 to 2013. We use generalized autoregressive conditional heterogeneity (GARCH) time-series models to assess the impact of the handover on business formation among both local and non-local companies. We specify models that allow us to estimate the effects of the build-up to the transformation as well as its after-effects. We also specify models that allow for detection in changes in variability over time in business registrations in response to the handover. These specifications can be taken as tests of the theoretical arguments developed earlier. In the models estimated for these tests, we include controls for the general state of Hong Kong's economy and population as well as other factors relevant to new business creation. To provide a plausible counterfactual scenario, we conduct a similar analysis of business registrations in Singapore over the same period.

\section{Hong Kong's Political Transformation}

Originally part of China, Hong Kong Island was ceded to the United Kingdom in 1842 with the signing of the Treaty of Nanking. The treaty ended the First Opium War and made the island a perpetual possession of Britain for use as a port. The Convention of Peking, signed in 1860, ended the Second Opium War and ceded in perpetuity to the British the land forming the peninsula immediately across from Hong Kong Island, known as Kowloon. In 1898, the so-called Second Convention of Peking was signed, granting Britain a 99-year lease on the surrounding land, known as the New Territories. Together, these three parcels, which Britain ruled from 1898, constituted the political territory the world recognized as Hong Kong through most of the twentieth century.

In the late 1970s and early 1980s, the pending expiration of the New Territories' 99-year lease prompted negotiations over the future of Hong Kong. The discussions involved the fate of all of Hong Kong's territory because first, the Chinese insisted on it, arguing that the perpetual treaties were invalid; and second, it was impossible to sustain so many inhabitants on the island and Kowloon without access to the natural resources (especially water) in the New Territories. The uncertain future rattled the Hong Kong economy. The British eventually acknowledged the inevitable and signed the Sino-British Joint Declaration in late 1984; this agreement gave up their sovereign rights to all of Hong Kong when the lease expired on June 30, 1997. The Joint Declaration also pledged that China would allow Hong Kong to retain its social and economic system while retaining a high degree of autonomy, even if ultimate sovereign authority did rest with the People's Republic of China.

Following the Joint Declaration, China and Britain worked together with local officials to design and manage a process to facilitate the handover. This process generated the Basic Law of the Hong Kong Special Administrative Region, which resolved many legal governance issues con- 
cerning defense, rights, currency, and the like. The Basic Law was first published in draft form in April 1988, and then again in February 1989; public commentary was invited. The final version of the Basic Law was promulgated by the National People's Congress of the PRC in April 1990. It took effect at the time of the handover.

The longer than twelve-year interim from the Joint Declaration to the handover proved to be an emotional roller coaster ride for the Hong Kong population. On one hand, much of the worst uncertainty had apparently been resolved, and the transformation became potentially calculable. On the other hand, it became obvious to most observers that successful implementation depended almost entirely on the credibility, goodwill, and capability of the Chinese government. As the sole sovereign power in place after the handover, the PRC had the political authority to do just about anything it wanted with Hong Kong, regardless of any agreements or public promises. For example, Vickers (2001) quotes the press secretary of Governor Patten (the last British Governor of Hong Kong) as saying in private at the time, "It has become very clear that China is going to constrain it, that it never intended to give Hong Kong a high degree of autonomy." Nevertheless, many residents and observers became optimistic about the future despite the threat of economic and diplomatic losses if China backpedaled on the agreements. Many also regarded reunification as resolving a long-standing political problem and anticipated that Hong Kong would serve as a major conduit for economic activity into and out of China.

Against this backdrop, the British and Chinese governments continued to squabble from time to time, often because Britain rushed to implement unprecedented democratic reforms in Hong Kong in hopes of forcing the Chinese to make them permanent. Reflecting continued anxiety about the issue, emigration from Hong Kong picked up dramatically at times, reaching a peak in 1992 (Salaff, Shik, and Greve 2008). During this period, several highly visible businesses diverted assets away from Hong Kong, raising further alarms. Still, by early 1997 public polls showed that more than 60 percent of the Hong Kong population expressed optimism about the future of Hong Kong's economic performance (DeGolyer 1997).
The handover itself went seamlessly. Despite much fanfare and widespread invocation of symbols, the glaring spotlight of the international press failed to uncover any scandalous incidents or any foul-ups of true significance. The PRC rapidly implemented the Basic Law and appointed a Chief Executive, as well as organizing a legislative council that used mechanisms different from those the British had tried to leave in place. Meanwhile, Governor Patten and Prince Charles sailed off peacefully on July 1, 1997, on the $H M Y$ Brittania after relinquishing the government.

The ensuing period may long be the subject of debate. With the Asian financial crisis of 1997, Hong Kong's real estate bubble burst and the economy went into recession. The Hong Kong government responded with a stimulus package that apparently ignited recovery. Meanwhile, tensions about who held ultimate legal authority persisted, especially when Hong Kong's Court of Final Appeal was overruled by Beijing in 1999. Later, the SARS epidemic ravaged the economy in the winter and spring of 2003. The next year, mass protests following an attempted promulgation of an anti-subversion law raised concerns in Beijing.

Analyses of the impact of political transformation on Hong Kong are inherently controversial because of the difficulty in comparing its history and development to those of other places (Martin 2007). No other place was truly comparable to Hong Kong before the handover, and few places have experienced social and economic forces similar to those non-political ones that have impinged on Hong Kong since the handover. (Singapore may be the closest in terms of economic position.) While the current status of Hong Kong can be assessed and compared to its pre-handover status, the attribution of causality depends on the counterfactuals assumed and involves disentangling many factors. We attempt to take these issues into account in the analyses below.

\section{Theoretical Considerations Re- garding Political Transformation}

To develop arguments about new business formation in Hong Kong during the handover period, we start with two basic theoretical themes regarding political transformation - uncertainty 
and opportunity. We briefly discuss each in turn and then attempt to reconcile them with and integrate them into the Hong Kong case, where we develop specific propositions about how political transformation likely affected business foundings.

\section{Entrepreneurial Uncertainty in Political Transformation}

Political transformation, as we use the term here, implies broad systemic change in an institutionalized sovereign polity. Most political transformations entail a realignment between social groupings and societal resources (Skocpol 1979). From this point of view, a political transformation disrupts the social order; it creates - at least temporarily - some degree of uncertainty (Stinchcombe 1965). A political transformation also generates uncertainty because the role of the (new) government and the impact of its regulations are usually less predictable, thus obscuring the probabilities of particular events and outcomes (Knight 1921).

Politically induced uncertainty worries executives, entrepreneurs, and external investors; it causes many of them to act more conservatively, or leads them to consider alternative investment and career options. For the managers of firms, strategic adaptation to a changing political environment presents great challenges because the transformation is often not calculable and its outcomes are unclear (Dobrev 1999; 2001). Similar concerns rattle potential entrepreneursuncertainty scares off many of them and their investors and lowers the predictability of the proceses of both initiating organizing activity and moving from there to the actual start of business operations (Kuilman and Li 2006).

The twentieth century witnessed many major political transformations, including the demise of empires (in China, Germany, Russia, Turkey, and Austro-Hungary); the rise of state socialism (in Russia, China, and scores of underdeveloped countries); the emergence of authoritarian states (in Africa, the Middle East, and Latin America); the resurgence of theocratic states (in Iran and other Islamic states); the waxing and waning of democracy (in Central and South America); and the collapse of dominant extranational regimes (in the Soviet Union and the Eastern Bloc). Most of these transformations were generally unexpected or at least unpredictable in their timing until they were imminent. And, while they were occurring, observers and analysts often tended to view the unfolding of events as less than fully predictable.

So, political transformation generates uncertainty, and for that reason anticipated or looming political transformation is often regarded anxiously as detrimental to business, including new entrepreneurial activity. Uncertainty encompasses numerous factors, including labor rights, contract law, prospects for organizational and economic growth, and rules of trade. At the center of such immediate uncertainty is concern about the stability of property rights and consequent worries about recovering anticipated future returns on contemporaneous investment 3 As Acemoglu and Johnson (2005) define them, property rights institutions are "the rules and regulations protecting citizens against the power of the government and elites." The concern is not just about possible government expropriation but also about possible government enforcement of an economic context where the rules might tilt towards certain firms and actors close to those holding political power.

The period of uncertainty associated with a political transformation typically extends far beyond the actual political or legal events involved. When a new political system is established, credibility may be questionable. A first question often asked is whether the rules that were expected to be put in place were indeed those enacted. Then, even though certain specific rules might be installed initially, observers know that their implementation and enforcement matter enormously. 4 It takes time to observe, evaluate, and understand enforcement behavior; experience with a polity counts for a lot. In addition, the government itself needs to work out details of operation. These will usually be implemented by technocrats, and so the details may or may not prove to be fully consistent with the prior public claims of political leaders. Finally, as powerful interests challenge rules, the nerve and fortitude of the

\footnotetext{
${ }^{3}$ Contracting rights among exchange partners may also seem an important issue. However, empirical study suggests it to be of far less impact, as contracting partners can usually find their own solutions in the midst of weak state enforcement (Acemoglu and Johnson 2005).

${ }^{4}$ Consider, for instance, ex-IBM CEO Sam Palmisano: "Underpinning the intellectual property regime must be consistent enforcement..." (2014: 83).
} 
political elites and officials running the regime will be assessed to determine likely stability.

\section{Entrepreneurial Opportunity in Political Transformations}

A different view of political transformation focuses on the potential new opportunity that sometimes emerges as established markets are disrupted, if not undermined, and new markets arise (see Stinchcombe 1965). That is, political transformation induces change in socioeconomic alignments, altering ties between social groupings and resources by introducing new rules, whether formal or informal. So, at least for some actors, the advent of a new political system brings with it potential rewards, perhaps new or perhaps wrested from others, perhaps intended or perhaps happenstance. The possibility of capturing these potential rewards in a fast-changing environment should attract and encourage some entrepreneurs.

As North (1992) observes, "institutions are not necessarily or even usually created to be socially efficient; rather they, or at least the formal rules, are created to serve the interests of those with the bargaining power to create new rules." Thus the entrepreneurs who are attracted to an environment of political transformation may not necessarily be highly risk-seeking - they may just view the emerging new order as better suited to their interests. For instance, Simons and Ingram (2003) show that the kibbutz organizational form prospered in the era before the State of Israel was established; after the state developed, its prominence and role were diminished. Ingram and Simons (2000) also show that cooperative forms of organization arose and thrived under regimes with compatible (leftist) ideologies.

This alternative view builds on the assumption that entrepreneurs seek new, emerging, and unusual opportunities. Entrepreneurs attempt to spot these opportunities and exploit them before other, established players can gain positional advantage; entrepreneurs thrive by taking quick advantage of new resources. Accordingly, some entrepreneurs may anticipate and bet on the possibilities generated by a political transformation. As Hannan and Freeman (1989) observe, "periods of political crises and social revolution seem to be peak times for building new forms of organiza- tions." Accordingly, much research focused on the regeneration period after a major transformation documents how emergent organizational forms are legitimated and become prevalent (Fier and Woywode 1994; Fier 1998; Dobrev 1999; 2000; 2001; Spenner et al. 1998; Windzio 2003).

\section{Reconciling Uncertainty and Opportunity}

Uncertainty and opportunity reflect two opposite sides of the transformation coin. The forces in any transformation clearly generate both conditions. Even the most orderly, well financed, and most fully agreed-upon transformation induces some uncertainty simply because largescale change cannot be completely controlled and shielded from unexpected consequences. Conversely, even the most severe crackdown by a repressive government unsympathetic to private enterprise will share market access with some insiders and cronies who see the development as opportunity. The challenging question in analyzing any specific historical transformation concerns how strong the forces driving the two conditions are relative to each other: Which condition will dominate, uncertainty or opportunity?

To address this question, we attempt to build an analytical framework that we can use for Hong Kong. Obviously, analysis of the polity is central. As North (1992) observes, "it is the polity that defines and enforces property rights." But as Weingast (1995) explains, this creates a dilemma because "a government strong enough to protect property rights and enforce contracts is also strong enough to confiscate the wealth of its citizens." Overcoming the dilemma requires that the political system embrace an ideology that tolerates, if not supports, private property, and that its design include credible limits on state power. Thus in analyzing a transformation, a comparative analysis of the polities in place before and after the shift is key. The analysis should include the polities' ideologies, interests, capabilities, resources, experiences, and mechanisms that limit its power.

Given the clear and strong directional change in the polities involved in the transformations of the Eastern Bloc countries in the early 1990s, it was easy to determine that the opportunity condi- 
tion would dominate. Avowedly liberal party systems with capitalistic ideologies replaced singleparty systems that embraced state socialism. Further, the previously established business infrastructure was radically underdeveloped relative to the sizes and educational levels of the human populations. Conversely, as in Cuba in the 1950s, when autocratic socialist polities take over and start expropriating private property from the many and sanctioning enterprise only for a few, it is clear that uncertainty dominates.

But what about other, less radical (or more ambiguous) cases of transformation? How should we analyze which condition will dominate? What analytical tools might be applied? In our view, scrutiny of the polities remains relevant, but we also think that calculation of the relative demographic sizes of the interest groups likely to be affected - the potential winners and losersbecomes important. In other words, we suggest examining the relative sizes of the interest groups likely associated with the new and old polities to assess how many will be affected by each condition.

How to do this? We propose tackling the issue in two steps. First, identify and calibrate the rough demographic sizes of the major relevant socioeconomic groups positioned to be affected economically (whether adversely or beneficially) by the transformation. Second, assess how the forces generating uncertainty versus opportunity might impinge upon each group, especially in factors that matter to the formation of new business. The conclusion of this analysis may very well point to which group(s) and condition will dominate, thus allowing a general prediction about business formation.

This approach recognizes that anticipating either uncertainty or opportunity puts the focus on different aspects of the transformation that, although tightly interrelated in many real events, are analytically separable. For example, a change in government that keeps property rights constant but ousts a business interest group close to the old government in favor of a new group can be seen as creating opportunity for the new group. Supposing the new group is significantly larger demographically than the old group, then, on a broad scale, the transformation generated more opportunity than uncertainty. Conversely, if the change in government did not appreciably change the structure of the favored business elite but did apparently undermine certain property rights upon which they relied, then the transformation likely created uncertainty about investment return that would hamper business founding and other activity. So, predicting a transformation's impact on business entails: (1) identifying the specific demographic groups or classes with realistic market access who rely on property and estimating their relative sizes; and (2) analyzing how the expected changes in property rights associated with the change in polities might affect each group.

Such calculations will likely never be easy or precise and may be impossible in cases where the situation is too complex or subtle or not enough relevant information is available. However, if the political system undergoes radical transformation, the force of the processes involved may be so great and its direction so clear that one can confidently estimate what will occur in terms of of both uncertainty and opportunity. For example, when the Iron Curtain collapsed in 1990, plenty of uncertainty was created. However, at the same time the new polities forming in Russia, the former Soviet states, and most of the Eastern Bloc signaled that markets and property rights would be strengthened (from very low levels), and the demographic base that might realistically take advantage of them (potential entrepreneurs) looked greatly enlarged. The anticipated effect of unleashing property rights to such latent groups was so huge that it swamped concerns about an imperfect state (and the demise of the minuscule existing base of entrenched socialist "entrepreneurs"). The result was a massive wave of entrepreneurship and new business formation in all these countries (Fier and Woywode 1994; Spenner et al. 1998; Dobrev 1999).

\section{Uncertainty and Opportunity in Hong Kong's Handover}

The situation surrounding the Hong Kong handover was less clear, and obviously it was very different from the collapse of the Eastern Bloc. Britain's Hong Kong polity supported a longstanding, relatively unfettered, capitalistic system supported by an established legal system 
that was regarded by many as open and unencumbered. It both protected private property and allowed access by many. This system was being replaced by an avidly pro-capitalist polity that did not apparently face credible limits to its power, lacked full transparency to outsiders, carried a legacy of state socialism, and remained communist at least in name. The new system would not necessarily encroach on property rights or limit market access, and its leaders even made repeated public assurances to the contrary, as in the Basic Law. However, for some residents and observers, the lack of real limits on state power and the earlier history of the PRC's opposition to free market capitalism meant that caution was wise, at least initially. This reticence was reflected in public opinion polls right before the handover, in which the Chinese government received a low score from Hong Kongers on issues of trust; the polls also showed that more than two thirds of the populace held negative, ambivalent, or neutral feelings about the transformation (Sing 2001).

The demographic groups meaningfully involved in potential new business formation in this situation can be grouped into three categories: (1) those aligned with the British regime; (2) those aligned with the PRC regime and their local delegation; and (3) the Hong Kong locals. Quite obviously, allies of the British regime worried about their prospects in the transformed Hong Kong. This group was most closely aligned with the existing power and economic context. Any threat to property rights protection, or to the legal system and socioeconomic context that supported such protection (Acemoglu and Johnson 2005 ) would potentially undermine returns to their investments. This group also worried about whether the new government might provide unfair access and protection to business interests associated with the regime in Beijing. Accordingly, new business formation among this entrenched group likely declined, analagous to trends seen in other political transitions.

Political transformation in Hong Kong likely did unleash some new opportunities for entrepreneurs who wished to leverage the growing business connection between Hong Kong and mainland China. Under the colonial system, the monopoly-like power of business in certain scaledriven sectors was tolerated, if not encouraged, by some. Some entrepreneurs may have viewed the new Hong Kong as more accessible than before because some monopolies were potentially threatened; yet other entrepreneurs, aligned with the PRC and its reigning Party, may have gained easier access or have entered believing that they might possess some advantage. In both cases we would expect that, at least for the favored types of entrepreneurs and organizations, political change would have induced rather than impeded business activity, including startups. By 2001, four years after the handover, mainland China was the largest investor in the territory, with a total of US $\$ 122.8$ billion, accounting for perhaps 30 percent of new investment (Holliday, Ngok, and Yep 2004). However, we suspect that the relative demographic size of the base presented with these favored opportunities was not large, at least initially, and that it took them time to get fully engaged.

As for the local Hong Kong business community, including latent entrepreneurs, we suspect that the average individual anticipating investment in new business activity in a local Hong Kong company around the handover was apprehensive. Presumably most of the entrepreneurs and investors behind such potential ventures held reservations about the historically socialist PRC government. Even if the government's pro-capitalist pledges and recent behavior could be taken as evidence of permanent change, Weingast's (1995) fundamental dilemma remained operative: there appeared to be few, if any, credible checks on the power of the polity under the new system. As a correspondent of the magazine Asia Today put it in 1996:

Only months remain until Hong Kong is returned to China. Not surprisingly, this remains the major source of concern for those living and doing business in Hong Kong. "How can we be sure," people ask, "that the features which have made Hong Kong the vital and successful business centre it is today will continue after the handover? How can we be sure that Hong Kong's 'new masters' will understand that, above all, Hong Kong thrives on the confidence that both its own population and the outside world have in 
its ability to react quickly and appropriately to changing business fortunes; that key elements such as confidence in the rule of law are essential to the smooth running of this dynamic and hugely successful commercial centre? (Bergman 1996).

Ironically, the pro-capitalist stance of the PRC central government and its specific interactions with business elites in Hong Kong during the build-up to the handover might even have undermined people's faith in property rights and prompted them to reconsider business investment. As Hung (2010) observed, "keen to maintain Hong Kong's economic vitality throughout the transition period, Beijing cultivated the goodwill of the business elite, and increasingly prioritized their views." This cultivation can be seen in the composition of the Drafting Committee for the Basic Law; among 23 members from Hong Kong, magnates such as Li Ka-Shing and Pao Yue-Kong dominated. The articles of the Basic Law critical to social welfare, taxation, labor protection, collective bargaining, and political reform practically all conformed to the preferences of business elites. Through coalition with Beijing, a handful of Hong Kong's top capitalists minimized uncertainty, fortified existing advantage, and positioned themselves to take future potential opportunities when the political transformation actually occurred $\sqrt{5}$ However, worries about damage to the economic system were not unwarranted, as public anxiety was indeed raised by several controversial cases of apparently privileged resource access under the government-initiated economic recovery program in 2000 (Hung 2010).

\section{Business Formation Rates}

In sum, according to this analysis, many residents of Hong Kong-both British-affiliated and locals - would figure they potentially had much to lose by the change in regime; this sentiment likely strengthened the populace's increasingly visible democracy movement. In addition, local entrepreneurs had limited ability to exit the territory with capital and other assets intact. All of

\footnotetext{
${ }^{5}$ The steady rise in inequality in Hong Kong from the early 1980 s to the present may reflect this process.
}

these factors likely heightened uncertainty and thwarted initiation of new local businesses in the period leading up to the handover as well as the period following the handover. This heightened uncertainty is likely to have overshadowed the business opportunities that arose from the handover. In the period before the handover there was the plausible prospect of diminished property rights; the period after the handover was inherently ambiguous given the time needed for a new political system to establish a record of credibility (and uncertainty about whether this new system would in fact do so). Moreover, the number of potential new entrepreneurs associated with the PRC was likely not large, at least initially, and the movement of personnel and resources required to make up for the departures of British allies and the diminished optimism of locals would require significant time and support. Not surprisingly, empirical evidence shows that the market for initial public offerings deteriorated with the handover because of the dominance of uncertainty (Carey and Steen 2006). Thus we argue:

Proposition 1. Political transformation in Hong Kong lowered the founding rate of businesses from that to be expected from historical patterns of economic activity and population growth.

\section{Dynamics of Political Transformation}

Political transformation induces a shock to an economy - the rules of the game change suddenly When uncertainty prevails, some nervous entrepreneurs and investors stay away, fraught with anxiety about what might happen under the new polity. When opportunity prevails, entrepreneurs may fall over themselves rushing in, and the noise of the stampede may alert others and generate an even larger rush in a later phase.

As the new polity develops, it accumulates a record. The record consists of the actual decisions and experiences of various actors in the new political system, including political leaders, government officials, entrepreneurs, investors, property owners and employees. The record includes behaviors and statements that will be interpreted as revealing values, preferences, and policy positions; 
consistency in the record indicates a plausible future under the new system. Assuming political stability, a consistent record suggests the treatment that new actors of the same kind will likely receive - it reduces uncertainty and makes opportunities more transparent and calculable. Reducing uncertainty should increase the business formation rate, allowing it to rise gradually to a steady level. Making opportunities transparent and calculable should serve to temper any initial irrational exuberance the transformation may have ignited.

In any political takeover, agreements and other promises can only go so far in reducing uncertainty or making plain the extent of new opportunities. Hong Kong was no exception. Despite the Joint Declaration and subsequent agreements, it was widely understood that nothing was necessarily binding on the incoming sovereign state. Once the political transfer occurred, many different things could happen: sovereignty means supreme authority over a territory, and China would have sovereignty over Hong Kong.

As a result, uncertainty persisted in the immediate post-handover period. A public mood of anxiety and uneasiness prevailed, according to Liu (1999), who reported much grumbling among the population. Despite the Basic Law, it was impossible to know from a business perspective on July 1, 1997, what the exact firm-level consequences of the new political system would be. Legal analysts such as Rubenstein (1997) contributed to the uncertainty by noting structural challenges: "real private-law protection for entrants will require a fundamental rethinking of institutional arrangements which make up partystate rule."

With the passage of time, the new system and regime were seen, experienced, and evaluated; new rules and institutions were also put into place, and these gave some clues to the future. Although certain events and decisions, usually around the freedom of speech, occasionally garnered great media attention, most sober and dispassionate analyses recognized that the PRC and the new Hong Kong government had fulfilled their promises, especially as concerned private property and associated rights. Lanfang (1999) lauded the way in which a deal for arbitral awards was worked out and then guided subsequent judicial rulings. Sing (2001) declared that the Hong
Kong government had achieved legitimacy in the eyes of the public. Boniface and Alon (2010) judged that voice and accountability had actually increased since the handover, leading them to announce that, "China has largely honored the principle of one country, two systems after ten years."

The increased acceptance of, and comfort with, the new regime can be seen in emigration patterns. An official with the Consulate General of Canada - one of the more popular destinations for those leaving Hong Kong — said that although about 150,000 Hong Kongers had moved to Canada in the 15 years prior to the handover, patterns changed after the handover. "In the run-up to the handover, it was phenomenal, but now it's down to what we would consider a normal level" (South China Morning Post 1998). Identification with the new regime also became more common. A series of six surveys by Ma and Fung (2007) shows that Hong Kongers increasingly came to see themselves as similar to mainland Chinese, a development likely reinforced by acceptance of language changes (Ling 2012).

At the same time, new business opportunities started to emerge after the handover. Observers and analysts (Martin 2007) have noted, for instance, that Hong Kong's economy recovered strongly from the problems of the early posthandover period. After experiencing sluggishness during the Asian financial crisis and the SARS epidemic, the economy picked up considerably. Real Gross Domestic Product (GDP) grew at high annual rates of seven to eight percent during the middle of the current decade before slowing down. Per capita GDP remains at levels similar to many developed countries, and the legitimacy of the government is often attributed to this continued prosperity despite rising inequality (Hung 2010). In addition, the economic relationship between Hong Kong and China deepened at a fast pace; bilateral trade more than doubled in the decade following the handover. Although this might now seem an inevitable development, it was not considered so at the time of the handover, in large part because shipments of goods and materials to and from China were treated the same as from any foreign country. In most observers' assessments, the deepened interaction emerged from: (1) the economic slowdown of Hong Kong's other Southeast Asian national trading partners; (2) 
the institution of a free trade agreement between Hong Kong and China; and (3) the continued expansion of the tightly linked Pearl River Delta economic region (Holliday et al. 2004).

Thus we expect that entrepreneurial behavior rebounded as the record of the new polity lengthened. Uncertainty about the handover may have hampered business formation initially, but once the political consequences of the transformation could be directly observed, uncertainty subsided (because the post-handover experience showed that property rights were apparently secure) and new opportunities emerged. These developments took many years, and, as Dittmer (2011) recently noted, Hong Kong's integration is "still a work in progress." Thus we expect that

Proposition 2. The effect of Hong Kong's transformation on the business founding rate attenuated with time following the transformation.

\section{Dynamic Variability in Public Sentiment}

Despite its formal commitment to socialism, the incumbent PRC polity in the early 1990s actively supported market-based enterprise and had been moving in this direction for several decades. China is sometimes referred to as a "socialist market economy," reflecting its mixture of central command structures and market forces. State-owned enterprises dominate the economy and operate exclusively in industries regarded as strategic to national security, and for many years, private foreign firms were allowed to do business in China only through joint ventures with Chinese partners. However, in the last decade legal reforms have recognized and established private property rights, including those of private firms.

The PRC's promises about capitalism in the Basic Law naturally produced a certain level of enthusiasm from businesses that sought to locate in Hong Kong, whether as an entry point to China, for the local market, or for export reasons. The possible returns may have looked large to potential entrepreneurs, and if they could tolerate the risk, the calculation would have encouraged them to invest. For many, though, the risk may have seemed too high. A commonly perceived problem was that any pledge made by the PRC polity lacked full credibility: no real checks existed against its unconstrained authority and its overtly socialist counter-pledges. Whenever due diligence was conducted, however informal, this reality must have entered the calculation, especially among outsiders.

In essence, the pro-capitalist yet formally communist authoritarian polity represented an inherent contradiction to many observers and participants. This contradiction produced dramatic fluctuations in prevailing public opinion about the risks to freedom and property entailed in the handover. As a 1996 piece in the local newspaper described the situation:

A total of 50,000 people will have left Hong Kong by the end of 1996, compared with 46,000 last year, indicating continuing nervousness especially among the middle class after Hong Kong reverts to Chinese rule. But the figures, though considered high overall, also show that some degree of calm has set in. Although the situation remains volatile, the mood has eased up compared to two or three years ago, analysts say (Sharma 1996).

At times, individuals and businesses expressed fear, made plans to leave, or even actually emigrated. For instance, Jardine Matheson, one of the oldest British-owned companies in Hong Kong, moved its headquarters to Bermuda in 1984 and its stock listing to Singapore in 1994, in anticipation of the handover. Similarly, HSBC transferred assets to London under a new holding structure in 1991. At other times, the risks were glossed over and buried under waves of optimism about the resolution of Hong Kong's status and the gateway it would provide to China. In both instances, the actions of a few high-status actors were often widely interpreted as meaningful and produced waves of imitative behavior. The situation was exacerbated by the truly unpredictable and unknowable nature of the risk involved; almost any scenario seemed potentially plausible. Moreover, the high population density of Hong Kong fuelled rumors, as did the connections that many residents and visitors supposedly held with key mainland officials. The vibrant Hong Kong media also played a role in highlighting the many issues involved in the handover and framing them 
in many different ways, across outlets and over time (Pan et al. 1999; Qing 2000; Fung 2007; Flahery 2011; Oksanen 2011).

This mixed flow of optimism and pessimism likely affected business formation. In our assessment, such shifting sentiments probably colored even professional calculations about risk and generated volatility. If so, then it would have also produced greater-than-usual variance over time in startup activity, even if the average level of activity trended downward because of anxiety over property rights (Proposition 1). Again, we think that the effect might transcend the period of the actual handover itself. Anxiety obviously operated before the transformation, and the posthandover period was filled with equally many questions about rights amid possible regulatory changes. Would the PRC overrule the high court in Hong Kong? What would immigration policy be? Would the press be allowed to continue to operate freely? Would civil unrest occur? When would democratic elections be held for all political positions? As events unfolded after the transition, some encouraged widespread optimism while others spread pessimism. Thus we argue:

Proposition 3. Hong Kong's political transformation generated greater variance (volatility) in the founding rate of businesses, as public sentiment waxed and waned.

\section{Asset Mobility}

Among those firms that do enter a system under political transformation, the potentially unstable rules of the game likely make entrepreneurs and investors cautious and protective of their assets, to the extent possible. Organizations faced with substantial uncertainty are likely to position their assets to be mobile, at least until the uncertainty subsides. This may be true even for those who entered because they perceived favorable opportunities for their interests, as the structures supporting the opportunities may not be stable. As the New York Times noted in 1987,

... private capital is poised for flight. Many business people say they are planning to leave for other countries; what is holding them now, some say, are aged parents whom they are unwilling to leave. A Chinese builder, whose home is in Singapore but who has projects going in Hong Kong, said everyone he knows is holding as much money as possible in foreign currency, ready to leave Hong Kong quickly (Silk 1987: 2).

Williamson (1996: 331) describes the scenario in more general theoretical terms:

Investors who realize that they are disadvantaged in relation to other, more favored members of the society can and will adapt in a variety of ways. Thus more durable assets will be replaced by less durable; nonmobile assets will be replaced by more mobile; conspicuous assets will give way to those that can be sequestered; and assets may flee by relocating in more secure jurisdictions. More generally, non-redeployable investments that would be made if expectations were secure will give way to redeployable assets and capital flight and asset concealment. Productivity will be lost as a result.

To gain insight into the dynamics of this possible redeployment process, we propose consideration of what might be called the "organizational asset mobility ratio." We define this as the proportion of firms with more mobile organizational structures (that is, those that can be moved without undue effort) within the population of all firms. In Hong Kong, such differences in organizational mobility are reflected roughly by whether firms are registered as non-local firms (that is, branches of foreign firms) or local firms, including subsidiaries. Thus the organizational asset mobility ratio in Hong Kong is the proportion of non-local firms in the pool of all local and non-local firms.

The type of registration is a choice that the owners of the firm make. Non-local firms (foreign branches) are incorporated elsewhere; local firms and subsidiaries are incorporated in Hong Kong and are considered independent entities ${ }^{6}$ According to Lawrence (2005: 1),

\footnotetext{
${ }^{6}$ For non-local companies, the country of origin is also identified. Following the handover, the data show a downward trend in the number of companies registered from the United Kingdom, which conforms to the opportunity
} 
The business activities available to a company in Hong Kong are generally not dependent upon whether the company is locally incorporated, and there is generally little practical difference between operating a branch and a subsidiary company in respect of profit computation. The rate of tax levied on profits is the same for local and foreign companies, and dividends are not subject to separate taxation in Hong Kong.

Rather, the differences between local and nonlocal registration lie in the ease of initial setup and of liquidation, and in foreign tax advantages, local audit requirements, the assets that can be leveraged for credit, and the extent of legal liability. Non-local firms are easier to liquidate, can draw on the credit of the parent, might receive tax advantages from their home country (especially as concerns losses), can easily transfer profits to the parent (out of the country), and do not require separate audits on their Hong Kong operations.

Non-locals face potentially greater liability in that the parent firm can be sued in Hong Kong. Liability, however, is a complex issue that can be thwarted in many ways. For instance, should the firm decide to abandon the Hong Kong market, the issue might prove moot. Further, consider Cerutti, Dell' Ariccia, and Martínez Pería's (2007: 1671) analysis of international banks:

Branches are less common in countries with highly risky macroeconomic environments, where parent banks seem to prefer the "hard" shield of limited liability provided by subsidiaries to the "soft" protection of ring-fencing provisions. However, faced with risks

thesis - these could be regarded as the displaced or disfavored firms. Another interesting trend is the pronounced uptick of new companies from the Cayman Islands and the British Virgin Islands after the transition. Why would the individuals behind these companies view the change in political systems as a potential opportunity? The answer seems to be that many of them are actually mainland Chinese companies that incorporated in these places and then registered in Hong Kong to do business and obtain listings (South China Morning Post 2009). However, the situation behind every company is not readily knowable, and the motivations behind such maneuvers are not discernible from public records. stemming from possible government intervention and other major political events, parent banks are more likely to operate as branches. This is not necessarily surprising given the provisions that shield parent banks from the liabilities of their foreign branches in events such as wars, insurrections, or arbitrary actions by foreign governments. Under those circumstances, banks are actually more exposed as subsidiaries, which typically have higher capital and reserve requirements and larger investments in local fixed assets, relative to branches.

So it would seem that the liability risk to a parent facing a government takeover could be minimized in the case of a non-local or foreign branch, mainly because the takeover would not carry legal standing in the parent's home country and legal system.

By contrast, local firms or subsidiaries are easier to set up, and their liability risk is limited to their local shares, paid-in capital, and local investments. But setting up a local firm or subsidiary suggests a degree of commitment to the local market, as well as some confidence that new business opportunities lie ahead and that investments in these opportunities can be profitably made without being jeopardized by political events and actions. These factors make local firms (foreign subsidiaries) considerably less mobile and, depending on the home country, possibly more transparent. In our view, a political transformation that reduces the perception of business opportunities and increases uncertainty by threatening property rights should result in a greater proportion of non-local firms - that is, a higher organizational asset mobility ratio. We posit:

Proposition 4. Hong Kong's political transformation increased the average organizational asset mobility ratio among newly founded businesses.

\section{Dynamics of Asset Mobility}

As with business formation, the organizational asset mobility ratio should gradually adjust fol- 
lowing the shock of a political transformation, provided stability ensues. Again, the actual experience under the new system seems crucial; it gives entrepreneurs and investors a record of governmental regulatory behavior to observe and evaluate, which they use to assess the risks involved.

In Hong Kong, the early signals of the period around the Joint Declaration were interpreted as ambiguous, but these were followed by fairly consistent behavior indicating that the pledge to capitalism and private property could be taken as reliable. Business opportunities started to emerge as the economy picked up and interaction between mainland China and Hong Kong deepened. As a result of both decreased uncertainty and perceptions of new opportunities for aspiring entrepreneurs and business owners, we expect that the organizational asset mobility ratio will eventually revert back to its pre-transformation levels.

Proposition 5. The effect of Hong Kong's transformation on the organizational asset mobility ratio among newly founded businesses rate attenuated with the time following the transformation.

\section{Data}

The data we analyze describe information on local and non-local incorporations in Hong Kong from January 1975 to March 2013. The main source for this data is the Companies Registry in Hong Kong (Hong Kong Special Administrative Region, Various Years). Given that the Companies Ordinance legally requires registration of all corporations in Hong Kong, the available data is comprehensive and highly suitable for demographic analysis (Carroll and Hannan 2000). The dataset records observations over a period of 459 months in which 1,860,653 corporations were registered.

For the dependent variable, we use the monthly total number of corporations newly registered with the Hong Kong Companies Registry to test Propositions 1-3. Figure 1 shows the temporal trajectory of this variable over the period of the study. Obviously, registrations have gone up dramatically over the period, albeit in fits and starts at times. Note that Figure 1 reflects the gross count of registrations and does not necessarily reflect net values after controlling for socioeconomic factors and other time-varying covariates. Thus inferences should be made from this figure with caution.

We consider two major types of registrations. Domestic entrepreneurs and business owners generally register as a local business. Foreign entrepreneurs and business owners can opt to register as a non-local company or as a local business in Hong Kong. The foreign branches that result from non-local registration are not legally separable from their parent company. A local company registered by a foreign business, however, is legally a distinct entity, even if the parent owns all of the voting stock.

The number of local registrations far exceeds the number of non-local registrations: 18,239 registrations of non-local corporations and 1,842,414 of local corporations took place within our observation window. Figure 2 plots the historical trajectories of the two types (with numbers logged for ease of comparison). This figure shows an upward trajectory in registrations for both legal forms.

In studying the organizational asset mobility ratio, we rely on the normalized ratio of nonlocal registrations (foreign branches) as a proportion of all new firms in the territory. Since this ratio is bounded between 0 and 1 , we followed Tukey (1977) and used this logit transformation to make it follow a normal distribution: $\ln [$ Ratio/(1-Ratio)].

Our independent variables include a measure of the total number of registrations of local and non-local corporations in Hong Kong to capture any potential impact of a competitive or legitimating nature (Carroll and Hannan 2000). Density variables were lagged one month to address reverse causation 7

In addition, we used two overlapping period dummies. The Post-Joint Declaration period is coded as one for all months after December 1984, zero otherwise. The Post-handover dummy is coded as one for all months after July 1997, zero

\footnotetext{
${ }^{7}$ In exploratory analyses, we also investigated the possibility of non-monotonic relationships between business registrations and the total numbers of local and non-local corporations, as hinted at by ecological theory (Carroll and Hannan, 2000). The estimates proved not to be statistically significant.
} 


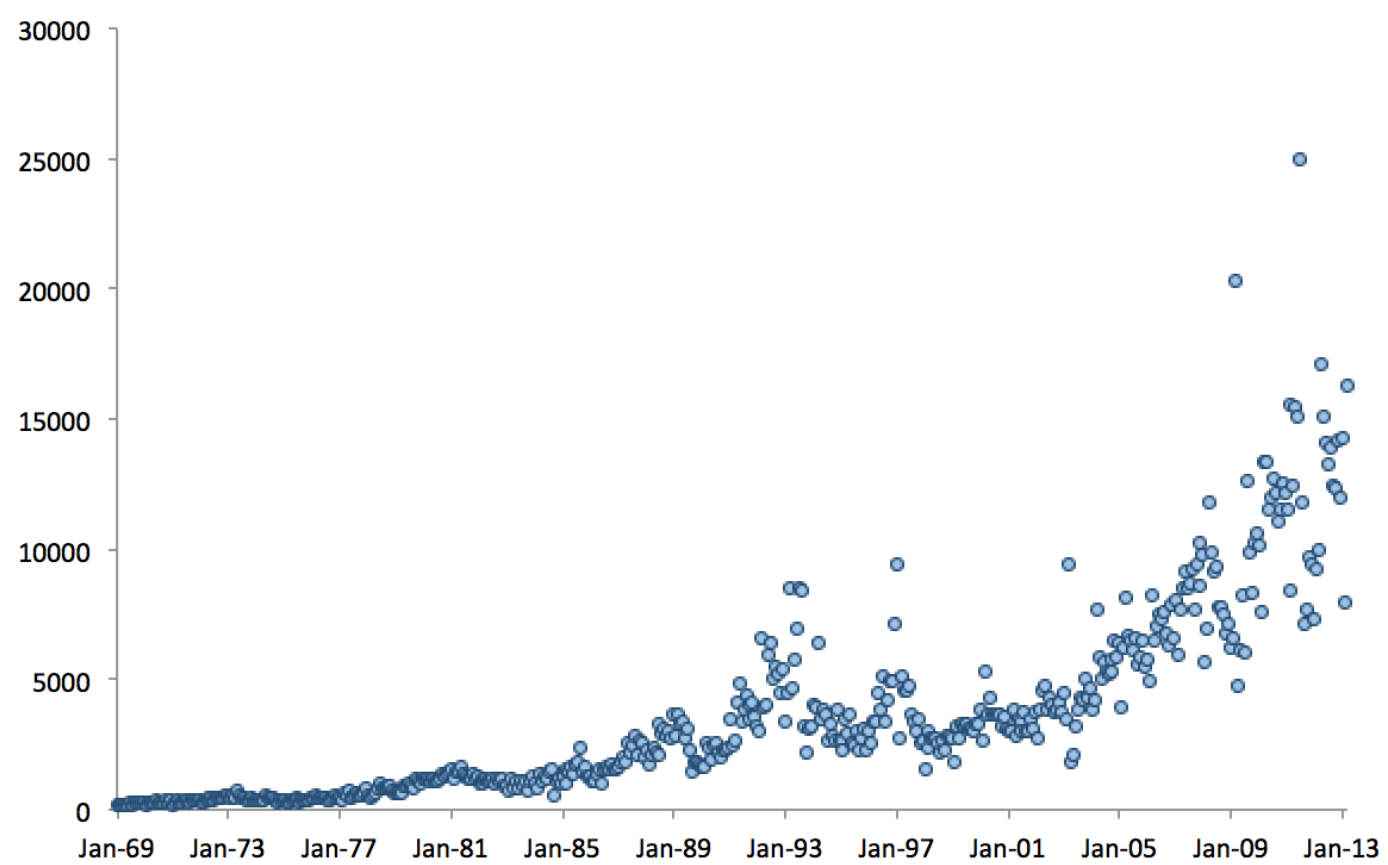

Figure 1: New Business Registrations in Hong Kong by Month 1975-2013

otherwise. With overlapping period dummies, the time period immediately preceding each dummy serves as the reference category. Two separate indicator variables were included to mark the corresponding events: one for December 1984, when the Sino-British Joint Declaration was signed and one for July 1997 to indicate the immediate impact of the handover itself. To study whether any effects the handover had on business formation abated or amplified with the growing number of months since the handover, we added a "clock" that is coded as zero prior to the handover, is coded as one in July 1997, and then increments by one each month up to a value of 188 in March 2013.

Finally, we controlled for a number of socioeconomic factors that could have affected business registrations in Hong Kong. To account for general levels of economic activity, we included the Gross Domestic Product (in HK\$ million at current market prices) with a one month lag. Since this variable was not available on a monthly basis for the entire observation window, linear interpolation was used in case of quarterly or yearly observations. Lending rates using the IMF International Financial Statistics were included with a one month lag. The Asian financial crisis affected Hong Kong from October 1997 (when stock markets crashed) to August 1998 (when they rebounded after substantial government spending). We also controlled for the impact of the recent global financial crisis, a period from December 2007 to December 2012. Finally, throughout our research window, we observed a sizable surge of new business registrations after each Chinese New Year ${ }^{8}$ mostly in March. We controlled for this Chinese New Year effect by including a dummy for March in our models.

To build a plausible counterfactual comparison case, we compiled similar data on Singapore. Although different in many respects, Singapore resembles Hong Kong in being a vibrant, advanced, city-based economy in Asia, with a roughly com-

\footnotetext{
${ }^{8}$ In societies where Chinese culture is dominant, like Hong Kong, Singapore, and mainland China, both business activities and public services would slow down considerably during the weeks immediately before and after the Chinese New Year, and pick up rapidly again when people resumed regular working schedules.
} 


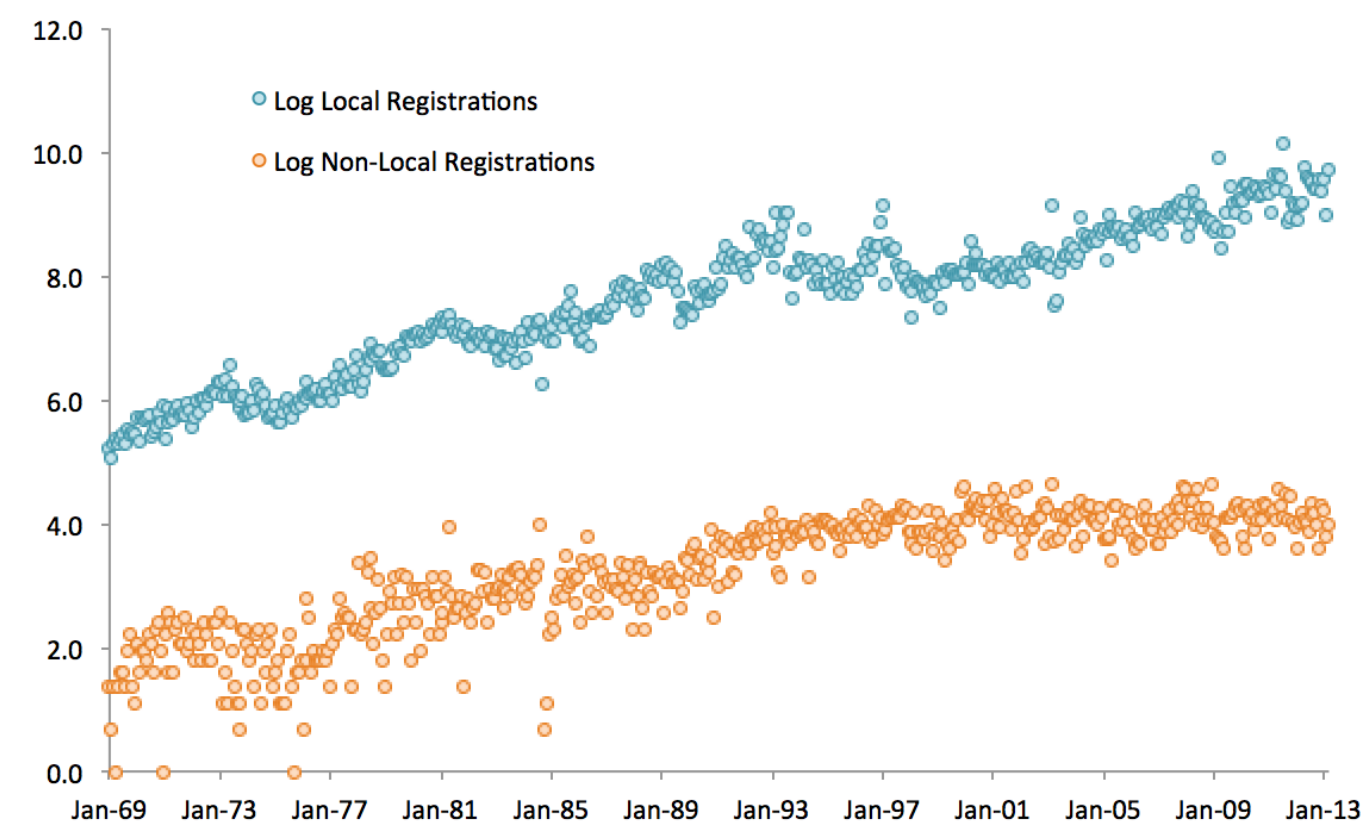

Figure 2: Comparing Monthly (Log) Local and Non-local New Registrations 1975-2013

parable economy, human population, and geography. Supplemental Appendix 1 lists major demographic and economic indicators for the two economies. Besides land size and population, Hong Kong and Singapore are quite comparable across these types of indicators in both magnitude and their respective ranks in the world economy. Regarding globalization, although Singapore depends on foreign trade more strongly than does Hong Kong, the latter remains a more attractive destination for foreign direct investment.

To state the obvious, however, Singapore did not experience a political transformation like Hong Kong's handover. Thus we estimate comparable models of business registrations in Singapore to see whether the patterns we observe in Hong Kong might reflect a more general regional pattern experienced in Singapore as well. The data on Singapore come from the Department of Statistics (Singapore Government, Various Years), which collects comprehensive statistical time series on Singapore's society and economy, including national accounts, investments, business expectations, trade, manufacturing, and demography. Because several variables of key interest were not collected by the Department of Statistics until 1980, we have to focus our comparative analyses between Hong Hong and Singapore on the post-1980 period only, which restricts the number of observations.

\section{Method}

We apply the autoregressive moving average (AR$\mathrm{MA}$ ) model integrated with the generalized autoregressive conditional heteroscedastic (GARCH) model to estimate the monthly number of new business registrations in Hong Kong. This method takes into account the special statistical properties of time series, as we discuss below, while making it possible to specify both the mean and variance effects of covariates in a single model.

A time series such as the registration data can be understood as a collection of random variables ordered according to the time they were observed. It differs considerably from other randomly sampled observations because the value in the past 
often affects the value in the future. This relationship, called autocorrelation or serial correlation, violates a critical assumption for ordinary least squares (OLS) regressions. This is essentially an assumption of independence, but it rarely holds for time series data. As a result, autocorrelation plagues the estimated standard errors obtained by the OLS. The structure of the autocorrelation becomes the focus of most statistical models trying to analyze time series data in an efficient and robust way (Tsay 2005). Moreover, in order for the OLS to be BLUE (best linear unbiased estimation), it also requires an assumption of homoscedasticity. This means that errors have to be normally and independently distributed with no change in the mean and variance:

$$
\varepsilon_{t} \sim N I D(\mu, \sigma) .
$$

Many time series data also violate this assumption due to the varying impact of unobserved factors over time. Yet sometimes the variance per se draws substantive research interest, as with the volatility in some financial data and the possible fluctuations in levels of new business formation discussed above in Proposition 3.

We combined the ARMA and GARCH estimation to address the above two issues. The ARMA model allows us to account for the dependence of the series by using $p$ autoregressive and $q$ moving average terms, whereas the GARCH model analyzes the conditional variance of the errors in a similar manner.

In the analysis, we attempted to isolate the effects of the handover by using dummy variables covering relevant periods. A first step in this strategy involved modeling in the $X$ vector socioeconomic control variables that might affect the business formation rate. These included the logged total number of business registrations, the logged GDP, the lending rate, a dummy for the Asian crisis (October 1997 to August 1998), a dummy for the global financial crisis (December 2007 to December 2012), a time trend (months since 1975), and a dummy for the Chinese New Year (March in each year). We then added, in various specifications detailed below, to the $X$ vector dummy variables for the Joint Declaration (December 1984) and the Post-Joint Declaration period (January 1985 to March 2013, the last observation month), the handover (July 1997), and the Post-handover period (August 1997 to March
2013). We also inserted a variable recording the number of months elapsed since the handover. In terms of Proposition 1, we expect that in modeling business formation rates, the coefficients associated with the Joint Declaration, the handover, and their post- periods to be negative. In line with Proposition 4, we expect the coefficients associated with these variables to be positive when modeling the organizational asset mobility ratio as the dependent variable. In terms of Propositions 2 and 5, respectively, we expect the variable recording the number of months elapsed since the handover to be positive in the modeling of business formations and negative in modeling the organizational asset mobility ratio.

The $\operatorname{ARMA}(p, q)$ model incorporates the correlation structure between $\varepsilon_{t}$ and its lagged realizations in the following form:

$$
\varepsilon_{t}=\sum_{i=1}^{p} \rho_{i} \varepsilon_{t-i}+a_{t}-\sum_{j=1}^{q} \theta_{j} a_{t-j}
$$

Here $\rho$ is the autocorrelation parameter and $\theta$ is the moving-average parameter. $a_{t}$ is a white noise series following iid normal distribution with zero mean and constant variance.

The conditional variance of $\varepsilon_{t}$ can also be incorporated into the specification. Specifically, the conditional variance, $E\left(\varepsilon_{t}^{2} \mid X_{t-1}\right)=\sigma_{t}^{2}$, uses past information on the $X s$ (Engle 1982). The $\operatorname{GARCH}(m, k)$ for the conditional variance can be specified as:

$$
\sigma_{t}^{2}=\gamma_{0}+\sum_{i=1}^{m} \gamma_{i} \varepsilon_{t-i}^{2}+\sum_{j=1}^{k} \delta_{j} \sigma_{t-j}^{2}
$$

We can conceive the GARCH model as an ARMA equivalent to the conditional variance of the disturbances. Empirically, the conditional heteroscedasticity of errors in many time series can be adequately estimated by the $\operatorname{GARCH}(1,1)$ model (Tsay 2005) 9 To explain the conditional variance $\sigma_{t}^{2}$ other covariates can also be introduced in Equation (2). This is a useful approach to identifying the source of any volatility. We use

\footnotetext{
${ }^{9}$ The advantage of $\mathrm{GARCH}$ is that the generalized component $\delta_{j}$ helps to update the variance more promptly than the original ARCH specifications. As a result, fewer parameters are required to achieve satisfactory fitness.
} 
it here in analyzing Proposition 3 by including dummies for the Post-handover and Post-Joint Declaration periods, which are predicted to show positive coefficients.

For the reasons above, we chose the $\operatorname{ARMA}(1,1)$ and $\operatorname{GARCH}(1,1)$ model to estimate the monthly new business registrations in Hong Kong and Singapore between 1975 and 2008. Potentially we could use any of three different forms of the dependent variable: the count of number registered $Y_{t}$, its first difference $\left[y_{t}-y_{t-1}\right]$, or the $\log$ transformation of this variable $\ln \left(y_{t}\right)$. The Dicky-Fuller test reveals that the first difference is by itself a stationary process, whereas both $y_{t}$ and $\ln \left(y_{t}\right)$ are stationary with a positive time trend.

We chose to use the count itself as the dependent variable for two main reasons. First, our research interest is focused on the level of entrepreneurial activities in Hong Kong amid political transformation, and its variance over time. The log-transformed data would artificially suppress volatility because it is informed by the rate of growth or decline, rather than the actual observation. We do not want the estimates to be affected heavily by the selected functional form of the dependent variable.

Second, the count as dependent variable has several advantages over the first difference in our view. Not only is the count more straightforward in interpretation, it also allows our model to have a more flexible serial relationship between observations. That is, the combination of $\operatorname{ARMA}(1,1)$ and $\operatorname{GARCH}(1,1)$ is a dynamic option to model the serial relationship for $y_{t}$ and the conditional variance of its errors, rather than forcing the transformation in the form of first difference. We thus use the count as the dependent variable.

The autocorrelation function $(\mathrm{ACF})$ plot suggests that the dependent variable is not serially independent, which justifies our choice of autoregressive models. Based on the above discussion, our regression model can be specified as:

$$
Y=X \beta+\varepsilon
$$

In Equation (3), $Y$ is the monthly business registrations, $X$ includes all the independent variables, and the serial relationship of the error term $\varepsilon$ and its distribution follow Equations (1) and (2), respectively.

\section{Findings}

Table 1 displays initial estimates of the effects of the handover of Hong Kong's sovereignty back to the PRC. It gives estimates of the effects of covariates on the number of newly registered corporations in Hong Kong.

Model 1 offers a baseline test about the impact of the transformation before and after July 1997. It shows that the monthly number of new registrations exhibits a positive time trend, as the Dickey-Fuller stationary test (Dickey and Fuller, 1979) has shown. This trend operates after taking into account the potential time-varying effects of other covariates such as total company registrations, GDP, lending rate, and economic fluctuations like the Asian crisis and the global financial crisis. Among these variables, the total number of company registrations, in its log transformation with a one-month lag, has a negative effect on the monthly change of new registrations. This finding suggests diffusive competition in an overcrowded market. As expected, GDP in Hong Kong, an indicator of the overall volume of business activities, encourages current new registrations. Model 1 also indicates that the lending rate, measuring the cost of financing, exhibits no effect on our dependent variable. The period of the Asian economic crisis did not affect Hong Kong's new business registrations, and new registrations became even more active during the global financial crisis, likely due to the massive stimulus packages in Hong Kong and mainland China. Model 1 also captures the Chinese New Year delay for business activities, which usually catches up considerably in March.

Model 1 also presents the ARMA and GARCH estimations, intended to identify the correlation structure of the error term and its variance. We see a positively significant $\mathrm{AR}(1)$ and a negatively significant $\mathrm{MA}(1)$ process in the errors. Both the $\mathrm{ARCH}(1)$ and $\mathrm{GARCH}(1)$ parameters are positively significant. The ARMA and GARCH parameters provide strong evidence of both serial correlation and conditional heteroscedasticity among the errors.

In order to assess the immediate and subsequent impact of the handover, an initial test of Proposition 1, we use two binary variables: the July 1997 single-month dummy and the Posthandover dummy that spans August 1997 to 
Table 1: GARCH Estimates of Effects of Handover on New Business Registrations

\begin{tabular}{|c|c|c|c|}
\hline & Model 1 & Model 2 & Model 3 \\
\hline Time (Months since Jan 1975) & $\begin{array}{r}61.965^{\dagger} \\
(3.712)\end{array}$ & $\begin{array}{r}46.080^{\dagger} \\
(13.078)\end{array}$ & $\begin{array}{r}47.264^{\dagger} \\
(13.369)\end{array}$ \\
\hline Handover (July 1997) & $\begin{array}{c}-2477.019 \\
(1874.324)\end{array}$ & $\begin{array}{r}-2594.850^{\dagger} \\
(636.406)\end{array}$ & $\begin{array}{r}-2514.657^{\dagger} \\
(632.017)\end{array}$ \\
\hline Post-Handover (Aug 1997 - Mar 2013) & $\begin{array}{r}-3885.086^{\dagger} \\
(334.841)\end{array}$ & $\begin{array}{r}-4053.415^{\dagger} \\
(761.339)\end{array}$ & $\begin{array}{r}-3882.851^{\dagger} \\
(731.988)\end{array}$ \\
\hline Months since Handover & & $\begin{array}{c}18.495 \\
(17.034)\end{array}$ & $\begin{array}{c}20.506 \\
(15.222)\end{array}$ \\
\hline Ln Total Registrations $t-1$ & $\begin{array}{r}-5653.404^{\dagger} \\
(516.190)\end{array}$ & $\begin{array}{r}-4061.804^{\dagger} \\
(1169.354)\end{array}$ & $\begin{array}{r}-4389.064^{\dagger} \\
(1433.972)\end{array}$ \\
\hline Ln GDP $t-1$ & $\begin{array}{r}975.250^{\dagger} \\
(318.711)\end{array}$ & $\begin{array}{c}930.817 \\
(740.623)\end{array}$ & $\begin{array}{l}1128.070 \\
(788.947)\end{array}$ \\
\hline Lending Rate $t-1$ & $\begin{array}{l}5.875 \\
(9.900)\end{array}$ & $\begin{array}{c}-10.883 \\
(11.173)\end{array}$ & $\begin{array}{c}-10.157 \\
(12.137)\end{array}$ \\
\hline Asian Crisis (Oct 1997-Aug 1998) & $\begin{array}{c}324.329 \\
(252.229)\end{array}$ & $\begin{array}{l}184.216 \\
(282.810)\end{array}$ & $\begin{array}{c}101.451 \\
(136.498)\end{array}$ \\
\hline Global Financial Crisis (Dec 2007-Dec 2012) & $\begin{array}{l}2645.712^{\dagger} \\
(285.825)\end{array}$ & $\begin{array}{l}3854.022 \\
(2579.120)\end{array}$ & $\begin{array}{c}2996.737 \\
(2368.926)\end{array}$ \\
\hline Chinese New Year Effect & $\begin{array}{l}133.669 \\
(78.787)\end{array}$ & $\begin{array}{l}126.087^{\dagger} \\
(20.250)\end{array}$ & $\begin{array}{l}123.196^{\dagger} \\
(22.757)\end{array}$ \\
\hline Constant & $\begin{array}{l}45281.990^{\dagger} \\
(3539.170)\end{array}$ & $\begin{array}{r}30419.976^{\dagger} \\
(10737.487)\end{array}$ & $\begin{array}{r}31858.265^{\dagger} \\
(11630.574)\end{array}$ \\
\hline ARMA & & & \\
\hline $\operatorname{AR}(1)$ & $\begin{array}{r}0.902^{\dagger} \\
(0.019)\end{array}$ & $\begin{array}{r}0.913^{\dagger} \\
(0.033)\end{array}$ & $\begin{array}{r}0.924^{\dagger} \\
(0.031)\end{array}$ \\
\hline $\mathrm{MA}(1)$ & $\begin{array}{r}-0.687^{\dagger} \\
(0.049)\end{array}$ & $\begin{array}{r}-0.656^{\dagger} \\
(0.067)\end{array}$ & $\begin{array}{r}-0.679^{\dagger} \\
(0.061)\end{array}$ \\
\hline GARCH & & & \\
\hline $\operatorname{ARCH}(1)$ & $\begin{array}{r}0.763^{\dagger} \\
(0.089)\end{array}$ & $\begin{array}{r}1.026^{\dagger} \\
(0.403)\end{array}$ & $\begin{array}{r}0.845^{\dagger} \\
(0.334)\end{array}$ \\
\hline $\operatorname{GARCH}(1)$ & $\begin{array}{r}0.597^{\dagger} \\
(0.035)\end{array}$ & $\begin{array}{r}0.507^{\dagger} \\
(0.112)\end{array}$ & $\begin{array}{r}0.528^{\dagger} \\
(0.109)\end{array}$ \\
\hline Constant & $\begin{array}{l}1141.203 \\
(1467.031)\end{array}$ & $\begin{array}{c}1594.339 \\
(1858.040)\end{array}$ & $\begin{array}{r}7.592^{\dagger} \\
(0.807)\end{array}$ \\
\hline $\begin{array}{l}\text { GARCH Covariate } \\
\text { Post Handover (Aug } 1997 \text { - Mar 2013) }\end{array}$ & & & $\begin{array}{r}3.689^{\dagger} \\
(1.062)\end{array}$ \\
\hline $\begin{array}{l}\text { \# of Obs } \\
\text { Log Likelihood }\end{array}$ & $\begin{array}{c}459 \\
-3668.178\end{array}$ & $\begin{array}{c}459 \\
-3666.608\end{array}$ & $\begin{array}{c}459 \\
-3662.844\end{array}$ \\
\hline
\end{tabular}

${ }^{\dagger} p<0.05$ (two-tailed tests). 


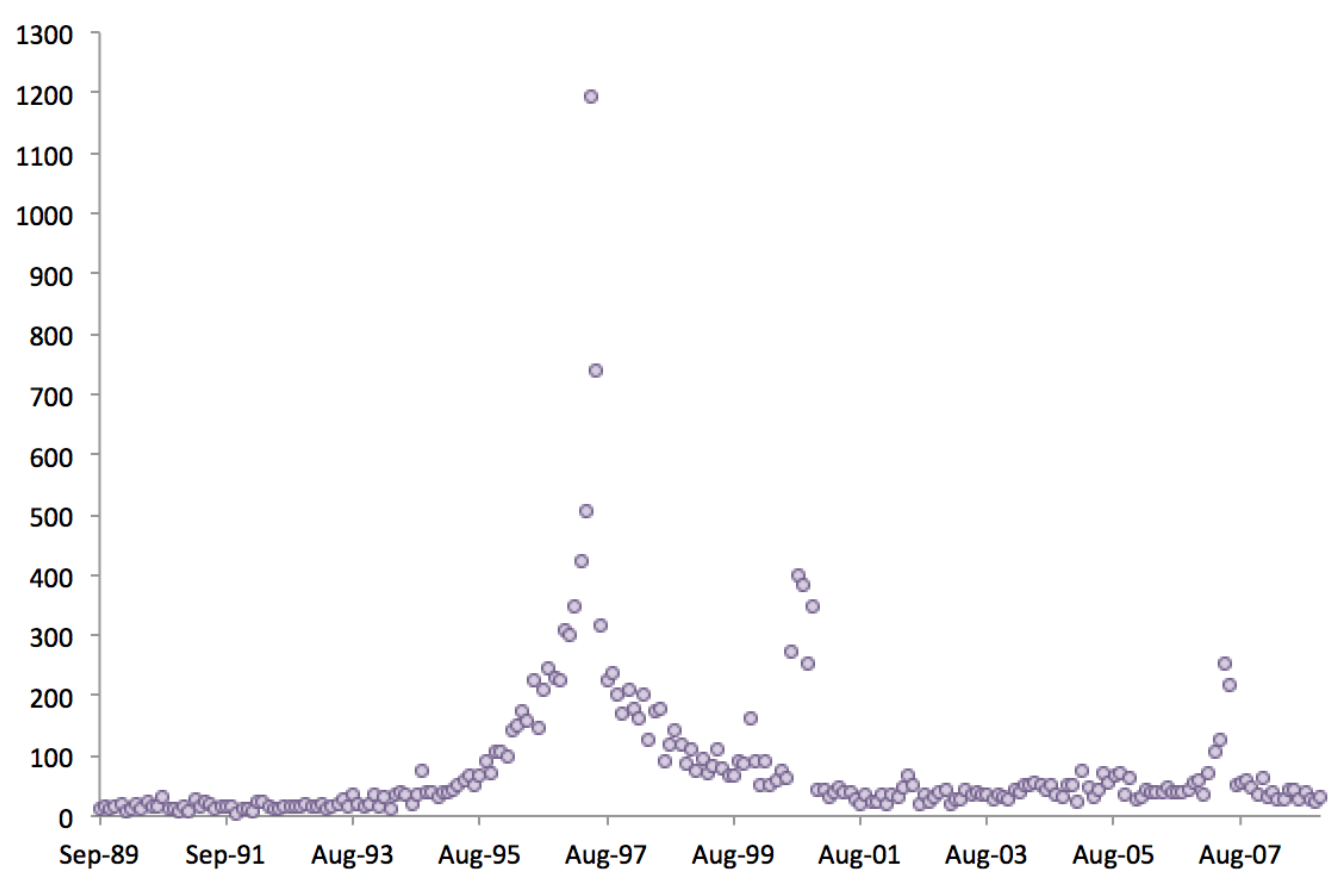

Figure 3: Monthly Count of Articles Mentioning "Handover" in SCMP

March 2013. Model 1 shows that new business registrations experienced a steep drop in July 1997, although the large standard error makes it not statistically significant. Although apparently a reaction to uncertainty created by the handover, we do not necessarily interpret the drop as a severely pessimistic immediate response of the business community to the transformation for two reasons. First, both government agencies and private sector entities likely shifted their priorities and attention towards the political transition and the related internal transformation in July 1997, thus neglecting some normal functions and reducing operational efficiency. Such distraction would likely negatively affect the number of business registrations. Second, sentiments of both anxiety and optimism struck strong notes at the actual handover, and this strange context alone could make potential entrepreneurs behave cautiously. Opportunities do not need to be taken at the very point when prevailing public sentiment is most heated.

sociological science | www.sociologicalscience.com

To track such sentiment, we counted the number of articles mentioning "handover" each month in the South China Morning Post (SCMP), a mainstream and popular English newspaper in Hong Kong. (See Figure 3 for the plot.) In both June and July of 1997, issues of the newspaper contain greater than ten times the average mentions of other periods. Such temporal fluctuation does not necessarily mean potential entrepreneurs changed their fundamental beliefs about future business prospects, but it could still have deterred new registrations.

Compared to the July 1997 dummy, the company registration pattern in the post-handover period is a more valid indicator regarding the systematic shift in the business environment. The estimates in Model 1 suggest that, on average, the number of new business registrations declined by 100 per month after the handover of Hong Kong's sovereign right, which is about 20.0 percent below the expected level (constant) if there were no transition. This finding gives strong support 
Table 2: GARCH Estimates of Effects of Source of Temporal Volatility on New Registrations

\begin{tabular}{|c|c|c|c|}
\hline & Model 4 & Model 5 & Model 6 \\
\hline Time (Months since Jan 1975) & $\begin{array}{l}21.738^{\dagger} \\
(2.669)\end{array}$ & $\begin{array}{r}24.715^{\dagger} \\
(6.499)\end{array}$ & $\begin{array}{r}29.495^{\dagger} \\
(7.267)\end{array}$ \\
\hline Joint Declaration (Dec 1984) & $\begin{array}{c}370.746 \\
(223.567)\end{array}$ & $\begin{array}{c}48.940 \\
(346.166)\end{array}$ & \\
\hline Post-Joint Declaration (Jan 1985 - Mar 2013) & $\begin{array}{l}1200.640^{\dagger} \\
(302.967)\end{array}$ & $\begin{array}{c}660.578 \\
(561.529)\end{array}$ & \\
\hline Handover (July 1997) & $\begin{array}{r}-1866.264^{\dagger} \\
(501.288)\end{array}$ & $\begin{array}{r}-1705.042^{\dagger} \\
(613.488)\end{array}$ & $\begin{array}{r}-1825.351^{\dagger} \\
(627.079)\end{array}$ \\
\hline Post-Handover (Aug 1997 - Mar 2013) & $\begin{array}{r}-2935.232^{\dagger} \\
(683.898)\end{array}$ & $\begin{array}{r}-2694.341^{\dagger} \\
(882.520)\end{array}$ & $\begin{array}{r}-2878.369^{\dagger} \\
(1052.221)\end{array}$ \\
\hline Months since Handover & $\begin{array}{c}38.09^{\dagger} \\
(10.119)\end{array}$ & $\begin{array}{r}40.684^{\dagger} \\
(14.742)\end{array}$ & $\begin{array}{r}43.150^{\dagger} \\
(15.565)\end{array}$ \\
\hline Ln Total Registrations $t-1$ & $\begin{array}{r}-2198.604^{\dagger} \\
(115.440)\end{array}$ & $\begin{array}{r}-2490.074^{\dagger} \\
(303.122)\end{array}$ & $\begin{array}{r}-2922.166^{\dagger} \\
(367.871)\end{array}$ \\
\hline $\operatorname{Ln}$ GDP $t-1$ & $\begin{array}{r}748.752^{\dagger} \\
(203.834)\end{array}$ & $\begin{array}{c}772.267 \\
(616.899)\end{array}$ & $\begin{array}{r}813.763 \\
(530.759)\end{array}$ \\
\hline Lending Rate $t-1$ & $\begin{array}{c}5.123 \\
(8.431)\end{array}$ & $\begin{array}{c}5.479 \\
(13.863)\end{array}$ & $\begin{array}{c}5.141 \\
(9.274)\end{array}$ \\
\hline Asian Crisis (Oct 1997-Aug 1998) & $\begin{array}{c}43.699 \\
(140.206)\end{array}$ & $\begin{array}{c}13.470 \\
(149.599)\end{array}$ & $\begin{array}{r}24.485 \\
(164.925)\end{array}$ \\
\hline Global Financial Crisis (Dec 2007-Dec 2012) & $\begin{array}{c}3085.327 \\
(1947.346)\end{array}$ & $\begin{array}{c}2624.092 \\
(1780.710)\end{array}$ & $\begin{array}{c}2490.696^{\dagger} \\
(1264.053)\end{array}$ \\
\hline Chinese New Year Effect & $\begin{array}{r}113.956^{\dagger} \\
(9.804)\end{array}$ & $\begin{array}{c}112.438^{\dagger} \\
(15.584)\end{array}$ & $\begin{array}{c}114.295^{\dagger} \\
(15.835)\end{array}$ \\
\hline Constant & $\begin{array}{c}14657.842^{\dagger} \\
(1226.026)\end{array}$ & $\begin{array}{c}17252.240^{\dagger} \\
(3907.276)\end{array}$ & $\begin{array}{c}20995.731^{\dagger} \\
(4590.113)\end{array}$ \\
\hline \multicolumn{4}{|l|}{ ARMA } \\
\hline $\operatorname{AR}(1)$ & $\begin{array}{r}0.921^{\dagger} \\
(0.035)\end{array}$ & $\begin{array}{r}0.946^{\dagger} \\
(0.046)\end{array}$ & $\begin{array}{r}0.964^{\dagger} \\
(0.026)\end{array}$ \\
\hline $\mathrm{MA}(1)$ & $\begin{array}{r}-0.689^{\dagger} \\
(0.062)\end{array}$ & $\begin{array}{r}-0.739^{\dagger} \\
(0.063)\end{array}$ & $\begin{array}{r}-0.765^{\dagger} \\
(0.055)\end{array}$ \\
\hline \multicolumn{4}{|l|}{ GARCH } \\
\hline $\operatorname{ARCH}(1)$ & $\begin{array}{r}1.041^{\dagger} \\
(0.250)\end{array}$ & $\begin{array}{c}0.897^{\dagger} \\
(0.251)\end{array}$ & $\begin{array}{r}0.943^{\dagger} \\
(0.263)\end{array}$ \\
\hline $\operatorname{GARCH}(1)$ & $\begin{array}{r}0.458^{\dagger} \\
(0.064)\end{array}$ & $\begin{array}{c}0.41^{\dagger} \\
(0.090)\end{array}$ & $\begin{array}{r}0.408^{\dagger} \\
(0.107)\end{array}$ \\
\hline Constant & $\begin{array}{c}5.285 \\
(3.199)\end{array}$ & $\begin{array}{r}6.875^{\dagger} \\
(2.036)\end{array}$ & $\begin{array}{r}6.903^{\dagger} \\
(1.737)\end{array}$ \\
\hline GARCH Covariate & & & \\
\hline Post Joint Declaration (Jan 1985 - Mar 2013) & & $\begin{array}{r}4.571^{\dagger} \\
(1.890)\end{array}$ & $\begin{array}{r}4.783^{\dagger} \\
(1.554)\end{array}$ \\
\hline Post Handover (Aug 1997 - Mar 2013) & $\begin{array}{c}6.031 \\
(3.180)\end{array}$ & $\begin{array}{c}0.559 \\
(0.773)\end{array}$ & \\
\hline \# of Obs & 459 & 459 & 459 \\
\hline Log Likelihood & -3652.492 & -3644.606 & -3648.293 \\
\hline
\end{tabular}

${ }^{\dagger} p<0.05$ (two-tailed tests). 
to Proposition 1, to the extent that the posthandover impact is concerned, where we argued that uncertainty over political assurance of property rights and the supporting legal system would discourage entrepreneurial activities.

Proposition 2 predicts that the decline in business registrations should gradually attenuate with time elapsed from the handover, given political stability and enforcement of property rights. Model 2 in Table 1 tests this proposition by adding a clock variable (Months since handover) that records the number of months since the handover. The estimated coefficient indicates that monthly new business registrations did not catch up with the level of the previous decades, although the net effect is still increasing when we take into account the overall positive trend of 46 per month since January 1975. Therefore, Model 2 in Table 1 does not support Proposition 2. This finding suggests that the negative impact of apparently diminishing property rights takes longer to dissipate than we expected.

As argued in Proposition 3, political transformation may not only matter to the average founding rate of new businesses but may also induce greater variation over time as optimism waxes and wanes. We explored the possibility of such an effect first in Model 3 of Table 1, then specified more fine-tuned tests in Table 2. Model 3 in Table 1 presents a straightforward result through the Post-handover dummy in the conditional variance component of the GARCH model (see Equation (3)). The estimated coefficient indicates that the monthly number of new business created displayed significantly greater variance (second order) after the handover. This effect may also help to explain the strong negative effect of the handover found in Model 2. Higher fluctuation suggests a more volatile underlying socioeconomic environment. If latent business owners behave more conservatively amid such business conditions, then we would expect to see a lower average founding rate.

Nevertheless, the prediction in Proposition 3 is not limited to the post-handover period. As documented above, anxiety obviously operated before the transformation, when the public expressed serious concerns about property rights and other relevant social economic rules. The predetermined nature of the political transformation in Hong Kong made it a unique setting to test whether and how such anxiety affects the volatility of new business foundings. In particular, the Sino-British Joint Declaration in December 1984 made it clear that the Chinese government would resume exercising sovereignty over Hong Kong from July 1, 1997. Such a long window of expectation is rare among political transformations of similar importance. With this motivation, we added two additional dummy variables to the analysis: Joint Declaration (December 1984) and Post-Joint Declaration (January 1985 to March 2013). Table 2 presents the estimates.

Model 4 is the baseline estimate, which shows that monthly new business registrations did not change significantly in the month of the Joint Declaration. The Post-Joint Declaration period even exhibits a notable increase in new business registrations. This indicates that Proposition 1 is not supported in terms of the negative impact of the handover on business foundings prior to July 1997.

But the pre-1997 impact of the handover's announcement can be more clearly seen in the variance in business registrations. We included the Post-Joint Declaration dummy in the GARCH estimation in order to identify the origins of the volatility observed for the post-handover period. Model 5 exhibits the results. It shows that the rate of new business founding experienced higher variance after the Joint Declaration, yet the actual transformation in 1997 and afterwards did nothing more than sustain such a level. This means that the average monthly founding of new businesses began to decrease after the handover, yet it started exhibiting higher volatility much earlier - starting with the Joint Declaration. On one hand, this finding implies that higher volatility does not necessarily lead to more conservative behavior as long as potential entrepreneurs hold an optimistic view of the opportunities brought by the transformation.

On the other hand, it also implies that people tend to overestimate the benefit of a political transformation and underestimate the inherent risk it involves. When the change actually occurs, a more realistic understanding of the business environment corrects the "excess" entries accumulated during the anticipatory period. Model 6 confirms this finding by summarizing the results in a more succinct specification (by removing the non-significant period effects). Altogether, the 


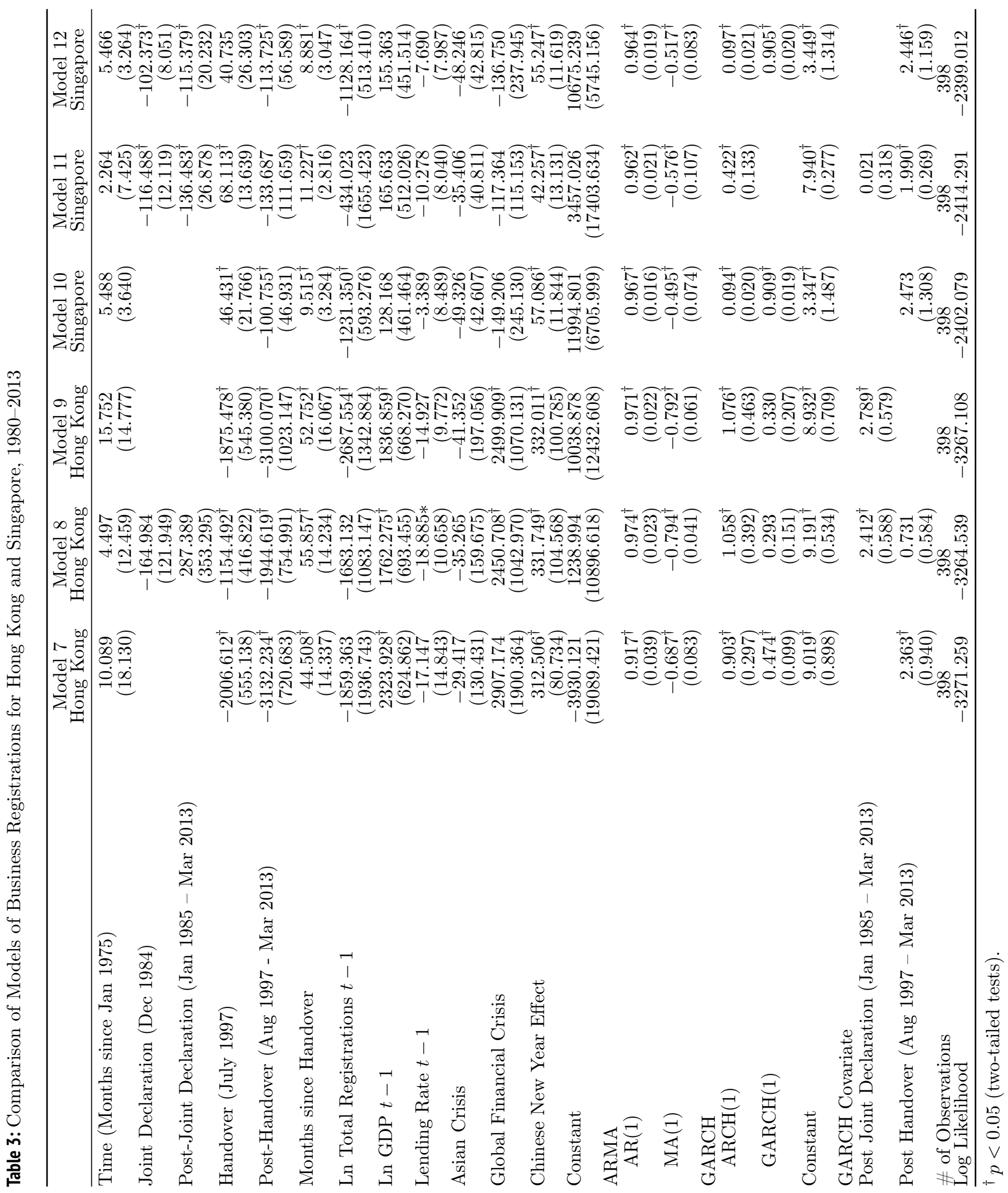


estimated results of our GARCH covariates from Model 3 to Model 6 provide strong support to Proposition $3{ }^{10}$ It is also worth mentioning that Proposition 2 receives strong support in Table 2, which improves the model fit significantly over Table 1, and in which the monthly clock after the handover becomes positively significant. This means that entrepreneurial behavior rebounds as anxiety about the potential negative consequences of the handover falls from its peak and confidence about the government's pledge to protect property rights gains ground.

It is possible, however, that the patterns we have identified in Hong Kong reflect other sweeping social and economic forces affecting the Asian region. The core issue is the counterfactual: What would have happened in Hong Kong if there had been no handover? While we can never answer this question definitively, we can perhaps get clues by looking at patterns in Singapore over the same period. Singapore is a good comparison to Hong Kong in terms of its GDP, per capita income, market institutions, and position in the global market. If powerful global or regional factors affected business formations in Hong Kong during this period, they would likely have affected Singapore as well.

Table 3 presents the comparison between Hong Kong and Singapore. Because major economic indicators were not systematically collected before 1980 in Singapore, we only focus on the period between 1980 and 2013. Models 7 to 9 replicate the analysis in Table 2 for this shorter period, which indicates no substantive changes to the earlier findings for Hong Kong. Models 10 to

\footnotetext{
${ }^{10}$ In order to further verify our propositions, we tried another dependent variable: the first difference of the log transformation of the monthly new business registrations, commonly used as a proxy to the rate of change in time series analysis. It is worth mentioning that each new registration by nature follows an arrival process; thus whether the rate of change is meaningful or not relies heavily on the time intervals used for aggregation. Also, as we mentioned earlier, the log transformation may suppress the volatility of the monthly count, one of our key research interests. Nevertheless, we were still curious about the period effect of this dependent variable and its volatility over time. Supplemental Appendix 2 presents the results. It is shown that our estimation exhibits no clear period effect on this variable, yet its volatility closely follows the pattern identified in Table 2. This finding boosts our confidence that new entrepreneurial activities experienced higher volatility from the Joint Declaration, much earlier than the actual political handover.
}

12 show the GARCH analysis estimates for new business formation in Singapore. These estimates suggest that historical changes in the business environments of Hong Kong and Singapore followed different patterns. Taking new registrations for example, entrepreneurial activities in Singapore became less active after the Joint Declaration, but in Hong Kong entrepreneurship did not experience a decline until the July 1997 handover, at which point the decline was of much greater magnitude. Furthermore, the GARCH estimation shows no effect by the Sino-British Joint Declaration on the volatility of business formation in Singapore, but greater volatility after July 1997. In Hong Kong, this volatility increased with the Joint Declaration. Overall, the divergent patterns that the comparison between Hong Kong and Singapore shows give us an additional layer of confidence in our inferences about the propositions.

Regarding the legal format of new business registrations, we argued in Proposition 4 that companies might prefer to establish their Hong Kong business entity as a foreign branch rather than as a local company or subsidiary due to the former's greater asset liquidity and profit mobility - significant advantages when anticipating a political handover to a polity with a different value system regarding property rights. Given data limitations, we cannot tell whether a foreign branch actually comes from a particular foreign parent company (including ones from mainland China), because almost every local citizen can setup a non-local entity and use it as the parent company to build a branch in Hong Kong. However, the longitudinal change in the ratio of newly registered foreign branches to overall new registrations (what we call the organizational asset mobility ratio) would still inform us about the shift of preference among business people.

With respect to Proposition 4, we argued that the organizational asset mobility ratio would likely increase after the handover. Table 4 presents estimates related to this argument.

Model 13 tests Proposition 4 in a basic GARCH regression. We used the normalized organizational mobility asset ratio as the dependent variable; the independent variables include only the most straightforward ones, such as the lagged organizational asset mobility ratio, the event and 
Table 4: GARCH Estimates of Effects of Handover on Organizational Asset Mobility Ratio

\begin{tabular}{|c|c|c|c|}
\hline & Model 13 & Model 14 & Model 15 \\
\hline Organizational Asset Mobility Ratio $t-1$ & $\begin{array}{c}0.872^{\dagger} \\
(0.078)\end{array}$ & $\begin{array}{r}0.879^{\dagger} \\
(0.068)\end{array}$ & $\begin{aligned} 0.864^{\dagger} \\
(0.068)\end{aligned}$ \\
\hline Time (Months since Jan 1975) & $\begin{array}{l}0.000 \\
(0.002)\end{array}$ & $\begin{array}{c}0.001 \\
(0.002)\end{array}$ & $\begin{array}{c}0.001 \\
(0.002)\end{array}$ \\
\hline Joint Declaration (Dec 1984) & $\begin{array}{r}0.546^{\dagger} \\
(0.269)\end{array}$ & $\begin{array}{c}0.319 \\
(0.211)\end{array}$ & \\
\hline Post-Joint Declaration (Jan 1985 - Mar 2013) & $\begin{array}{c}-0.046 \\
(0.057)\end{array}$ & $\begin{array}{c}-0.028 \\
(0.048)\end{array}$ & \\
\hline Handover (July 1997) & $\begin{array}{r}0.396^{\dagger} \\
(0.126)\end{array}$ & $\begin{array}{r}0.404^{\dagger} \\
(0.140)\end{array}$ & $\begin{array}{r}0.385^{\dagger} \\
(0.126)\end{array}$ \\
\hline Post-Handover (Aug 1997 - Mar 2013) & $\begin{array}{l}0.116 \\
(0.061)\end{array}$ & $\begin{array}{c}0.096 \\
(0.053)\end{array}$ & $\begin{array}{l}0.107 \\
(0.056)\end{array}$ \\
\hline Months since Handover & $\begin{array}{r}-0.002 \\
(0.002)\end{array}$ & $\begin{array}{r}-0.002 \\
(0.002)\end{array}$ & $\begin{array}{r}-0.003 \\
(0.002)\end{array}$ \\
\hline Ln Total Registrations $t-1$ & $\begin{array}{l}0.218 \\
(0.227)\end{array}$ & $\begin{array}{c}0.169 \\
(0.149)\end{array}$ & $\begin{array}{c}0.239 \\
(0.149)\end{array}$ \\
\hline Ln GDP $t-1$ & $\begin{array}{c}-0.175 \\
(0.309)\end{array}$ & $\begin{array}{r}-0.197 \\
(0.231)\end{array}$ & $\begin{array}{c}-0.305 \\
(0.209)\end{array}$ \\
\hline Lending Rate $t-1$ & $\begin{array}{c}-0.000 \\
(0.006)\end{array}$ & $\begin{array}{l}0.003 \\
(0.005)\end{array}$ & $\begin{array}{l}0.006 \\
(0.004)\end{array}$ \\
\hline Asian Crisis (Oct 1997-Aug 1998) & $\begin{array}{c}-0.039 \\
(0.031)\end{array}$ & $\begin{array}{c}-0.029 \\
(0.032)\end{array}$ & $\begin{array}{c}-0.024 \\
(0.031)\end{array}$ \\
\hline Global Financial Crisis (Dec 2007-Dec 2012) & $\begin{array}{c}-0.003 \\
(0.042)\end{array}$ & $\begin{array}{c}0.016 \\
(0.037)\end{array}$ & $\begin{array}{c}0.016 \\
(0.039)\end{array}$ \\
\hline Chinese New Year Effect & $\begin{array}{c}-0.116 \\
(0.076)\end{array}$ & $\begin{array}{r}-0.153^{\dagger} \\
(0.075)\end{array}$ & $\begin{array}{c}-0.128 \\
(0.074)\end{array}$ \\
\hline Constant & $\begin{array}{l}-1.180 \\
(1.061)\end{array}$ & $\begin{array}{r}-0.498 \\
(0.982)\end{array}$ & $\begin{array}{c}-0.331 \\
(0.931)\end{array}$ \\
\hline \multicolumn{4}{|l|}{ ARMA } \\
\hline $\operatorname{AR}(1)$ & $\begin{array}{c}0.123 \\
(0.099)\end{array}$ & $\begin{array}{c}0.123 \\
(0.084)\end{array}$ & $\begin{array}{c}0.121 \\
(0.079)\end{array}$ \\
\hline $\mathrm{MA}(1)$ & $\begin{array}{r}-0.739^{\dagger} \\
(0.135)\end{array}$ & $\begin{array}{r}-0.740^{\dagger} \\
(0.116)\end{array}$ & $\begin{array}{r}-0.716^{\dagger} \\
(0.107)\end{array}$ \\
\hline \multicolumn{4}{|l|}{ GARCH } \\
\hline $\mathrm{ARCH}(1)$ & $\begin{array}{c}0.213 \\
(0.133)\end{array}$ & $\begin{array}{r}0.127^{\dagger} \\
(0.063)\end{array}$ & $\begin{array}{c}0.146 \\
(0.076)\end{array}$ \\
\hline $\operatorname{GARCH}(1)$ & $\begin{array}{r}0.546^{\dagger} \\
(0.247)\end{array}$ & $\begin{array}{l}0.056 \\
(0.285)\end{array}$ & $\begin{array}{c}0.061 \\
(0.217)\end{array}$ \\
\hline Constant & $\begin{array}{c}0.039 \\
(0.031)\end{array}$ & $\begin{array}{r}-1.414^{\dagger} \\
(0.408)\end{array}$ & $\begin{array}{r}-1.422^{\dagger} \\
(0.327)\end{array}$ \\
\hline \multicolumn{4}{|l|}{ GARCH Covariate } \\
\hline Post Joint Declaration (Jan 1985 - Mar 2013) & & $\begin{array}{r}-0.929^{\dagger} \\
(0.271)\end{array}$ & $\begin{array}{r}-1.118^{\dagger} \\
(0.247)\end{array}$ \\
\hline Post Handover (Aug 1997 - Mar 2013) & & $\begin{array}{r}-0.326 \\
(0.205)\end{array}$ & \\
\hline \# of Obs & 459 & 459 & 459 \\
\hline Log Likelih & -203.357 & -181.095 & -183.497 \\
\hline
\end{tabular}

${ }^{\dagger} p<0.05$ (two-tailed tests). 


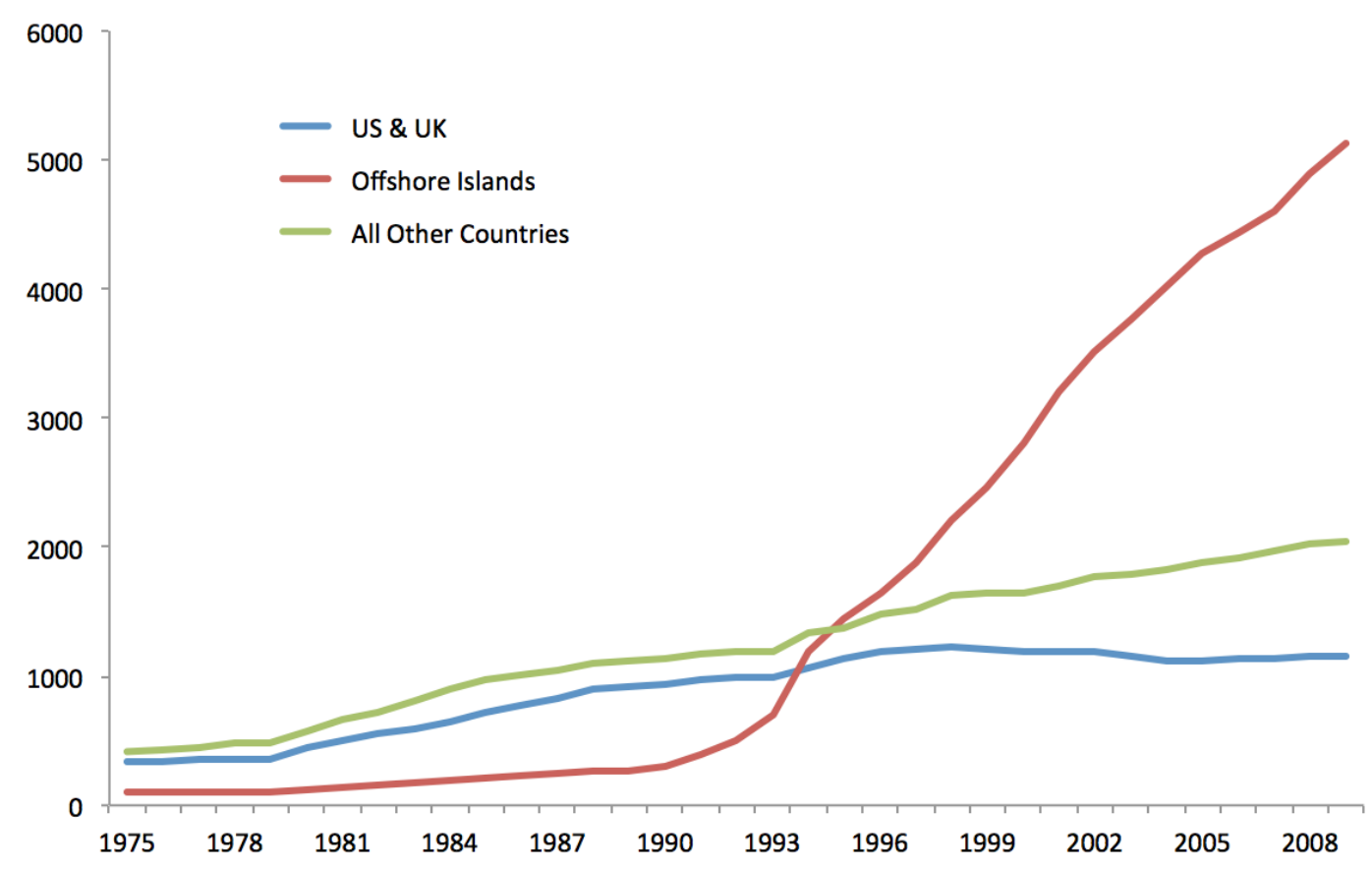

Figure 4: Total Non-local Registrations by Country of Origin (Note: Count of all other countries includes registratons from Mainland China)

period dummies, the time trend ${ }^{11}$ and the basic GARCH specifications. The estimated model suggests that there is indeed a significant increase in the ratio after the handover, as predicted by Proposition 4.

It is possible that this increase in the proportion of non-local branches may be driven simply by an inflow of companies from mainland China, who took the transition in Hong Kong as a change favorable to their advantage. Unfortunately, we do not have the registration breakdown by country at monthly intervals. Nevertheless, the yearly plots in Figures 4 and 5 suggest that companies from mainland China are not the primary drivers. Although the PRC number exhibits remarkable growth after 1997, the magnitude is smaller than that of the growth from offshore islands and other foreign countries except the United States and the

\footnotetext{
${ }^{11}$ Although the Dickey Fuller test indicates that the time series of the organizational asset mobility ratio is stationary without a trend, we still included an overall time trend to make sure that the results are comparable to the analysis of monthly new business registrations in Tables 1 through 3 .
}

United Kingdom. Firms coming from tax havens like the British Virgin Islands, the Cayman Islands, and Panama, are especially noteworthy because their presence grew by more than tenfold between the early 1990s and 2008. While we have no effective way to identify even the rough proportion contributed by mainland China firms, it is also obvious that the offshore islands are well positioned for protecting and even hiding wealth. Such advantages should resonate with the anxiety in Hong Kong regarding property rights.

Proposition 5 argues that over time entrepreneurs would make more accurate judgments based on the track record of the new regime; thus the registration ratio between local firms and foreign branches should become more balanced with time after the handover. The estimated result does not support this prediction, as time since the handover shows no significant effect. This non-finding may result from the minimal cost involved in setting up a foreign corporation for greater asset mobility. Model 14, which included the Post-Joint Declaration and Post-handover 


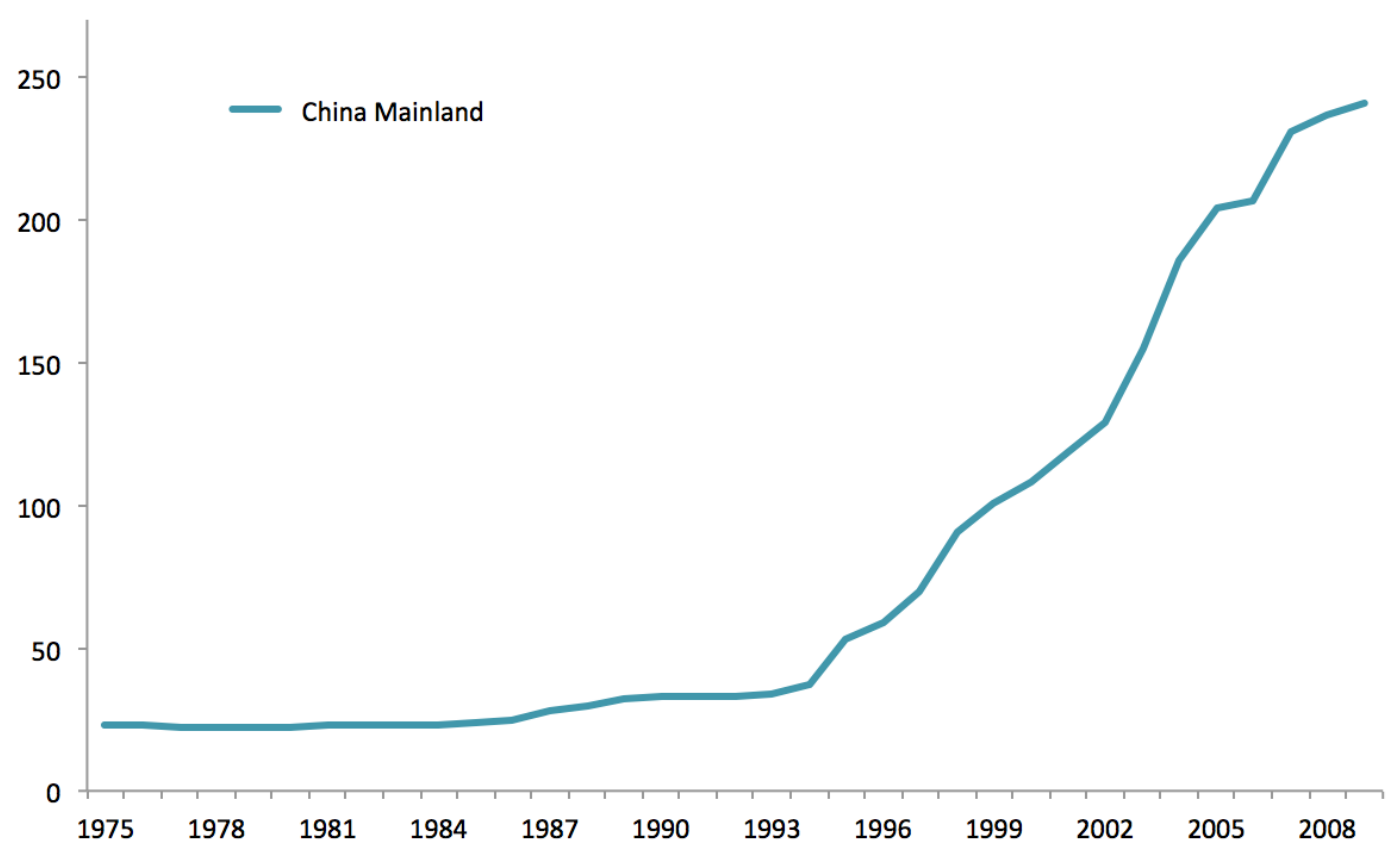

Figure 5: New Business Registrations in Hong Kong from Mainland China

dummies in the GARCH specification, continues to show support for Proposition 4. The volatility of the ratio also declines steadily after the Joint Declaration. This trend might be driven partially by the fact that there were quite few new foreign branches each month before 1984. The robustness of these findings is further verified in Model 15, where the non-significant Post-Joint Declaration period dummy is excluded in the main covariates and the Post-handover dummy in the GARCH estimation. Overall, Proposition 4 receives strong support, but we find no evidence for Proposition 5.

\section{Discussion}

Political transformations can affect business dynamics in profound ways, but the mechanisms by which this occurs have not been studied as much as their impact on society warrants. Political change will often seem to some extent idiosyncratic, as will its effects on the organizational landscape, but systematic processes that research can uncover are also surely at work. Accordingly, we assessed the Hong Kong handover not only because this important, unique global event deserves attention in its own right, but also because it provides a window through which we might better understand how political transformation affects business formation and other economic activity.

The Hong Kong handover stands out among political transformations because it was expected to happen and its precise timing was known well in advance. As the analysis shows, this did not mean there was no politically induced uncertainty. In fact, anxiety in Hong Kong waxed and waned, going from sheer optimism about its future under Chinese rule to public media proclamations about "The Death of Hong Kong" in 1995 (Fortune 1995). In this study, we found patterns in business registration data that reflect these fluctuations, in addition to registration rates that were lower in the period following the handover than would have been expected without it.

The findings also suggest that after the handover non-locally registered firms with greater 
asset mobility proliferated in greater numbers than did local ventures and subsidiaries.

Of course, it would be naïve to expect similar patterns to occur in all cases where a political transformation is expected to happen. Consider the shorter period between the fall of the Berlin Wall in November 1989 and the official reunification of East and West Germany in October 1990. Fier and Woywode (1994) demonstrated that business foundings in East Germany actually started to increase monotonically in the intervening period, peaking shortly before the actual reunification and showing little evidence of significant variance in founding rates. As Fier and Woywode (1994) noted, "the growing independence from plans and ideologies improves the development of more efficient and decentralized economic structures." Whereas in Hong Kong concerns about uncertainty alternated with optimism about improved opportunities, in East Germany the arrival of new business opportunities was so swift and clear that it dominated reaction to the change of polity. It may be that a longer period is required for oscillations to occur between the announcement of a political transformation and its actual implementation. Longer periods of time are almost by definition subject to more preparations, negotiations, and political jostling among parties involved. This behavior also fuels speculation among the general public as to what the implications of the political transformation will be.

The conceptual framework we developed here nevertheless helps to analyze the overall impact of a political transformation on business formation: whether or not the security of potential entrepreneurs' property rights is improved (or can be expected to improve) corresponds with whether opportunity-driven business formation or politically induced uncertainty will dominate the society's response to the change of polity. A corollary holds that the dominating force depends on the demographic size of the various bases affected by the political change. For instance, even if property rights are not guaranteed, opportunity-driven business formation can still dominate if a greater proportion of the population obtains beneficial treatment than had been the case before.

Theory building along these lines, in conjunction with deeper empirical examination of histori- cal cases of discontinuous political change, would contribute to a general understanding of how political transformation affects corporate demography. To this end, other aspects of dynamics at both the organizational and subunit levels need to be examined, such as organizational growth and change and employee mobility patterns. We look forward to studying such issues in future research.

\section{References}

Acemoglu, Daron. 2008. "Oligarchic Versus Democratic Societies." Journal of the European Economic Association 6(1):1-44. http: //dx.doi.org/10.1162/JEEA.2008.6.1.1

Acemoglu, Daron, and Simon Johnson. 2005. "Unbundling Institutions." Journal of Political Economy 113(5): 949-995.http://dx.doi org $/ 10.1086 / 432166$

Acemoglu, Daron, and James A. Robinson, J.A. 2012. Why Nations Fail. New York: Crown.

Amburgey, Terry L., Marjo R. Lahtisalo, and Dawn Kelly. 1988. "Suppression and Failure in the Political Press: Government Control, Party Affiliation, and Organizational Life Chances." Pp. 153-174 in Ecological Models of Organizations, edited by G. Carroll. Cambridge, MA: Ballinger.

Ash, Robert, Peter Ferdinand, Brian Hook, and Robin Porter, eds. 2003. Hong Kong in Transition: One Country, Two Systems. London: RoutledgeCurzon.

Bergman, P. 1996. "Economic Pulse is Strong and Healthy." Asia Today, October 1996.

Boniface, Dexter.S., and Ian Alon. 2010. "Is Hong Kong Democratizing?" Asian Survey 50(4):786-807. http://dx.doi.org/10 1525/as.2010.50.4.786

Carey, Peter, and Adam Steen. 2006. "Changing Conditions in the Hong Kong New Issues Market." Pacific-Basin Finance Journal 14(5):484-500. http://dx.doi.org/10 $1016 / j$.pacfin.2006.02.003

Carroll, Glenn R., and Michael T. Hannan. 2000. The Demography of Corporations and Industries. Princeton: Princeton University Press.

Cerutti, Eugenio, Giovanni Dell'Ariccia, and Maria S. Martínez Pería. 2007. "How 
Banks Go Abroad: Branches or Subsidiaries?" Journal of Banking \& Finance 31(6):1669-1692. http://dx.doi.org/10 1016/j.jbankfin.2006.11.005

Chan, Leo H. 2006. "A Note on the Correlation Relationship Among Singapore, Hong Kong and the US Capital Markets Since the Hong Kong handover." Singapore Economic Review 51(3):335-342.

Chong, Terence T., and Lily Lok. 2007. "The Impact of the 1997 handover on the Efficiency of the Hong Kong Stock Market." Singapore Economic Review 52(1):27-38.

DeGolyer, Michael. 1997. "The Political Transition and its Effects on Hong Kong's Civil Society." American Asian Review 15(4):195256.

DeLong J. Bradford, and Andrei Shleifer. 1993. "Princes and Merchants: European City Growth Before the Industrial Revolution." Journal of Law and Economics 36(2):671-702. http://dx.doi.org/10.1086/467294

Dickey, David A., and Wayne A., Fuller. 1979. "Distribution of the Estimators for Autoregressive Time Series With a Unit Root." Journal of the American Statistical Association 74(366):427-431. http://dx.doi.org/10 $2307 / 2286348$

Dittmer, Lowell 2011. "Introduction: The Continuing Relevance of Hong Kong." Asian Survey 51(4):581-583. http://dx.doi.org/10 1525/as.2011.51.4.581

Dobrev, Stanislav D. 1999. "The Dynamics of the Bulgarian Newspaper Industry in a Period of Transition: Organizational Adaptation, Structural Inertia and Political Change." Industrial and Corporate Change, 8(3):573-605. http://dx.doi.org/10.1093/icc/8.3.573

Dobrev, Stanislav D. 2000. "Decreasing Concentration and Reversibility of the Resource Partitioning Process: Supply Shortages and Deregulation in the Bulgarian Newspaper Industry." 1987-1992. Organization Studies, 21(2):383-404. http://dx.doi.org/10 1177/0170840600212004

Dobrev, Stanislav D. 2001. "Revisiting Organizational Legitimation: Cognitive Diffusion and Sociopolitical Factors in the Evolution of Bulgarian Newspaper Enterprises." 1846-1992.
Organization Studies, 22(3):419-444. http: //dx.doi.org/10.1177/0170840601223002

Drake, Leigh, Maximillan J. B. Hall, and Richard Simper. 2006. "The Impact of Macroeconomic and Regulatory Factors on Banking Efficiency: A Non-Parametric Analysis of Hong Kong's Banking System." Journal of Banking and Finance 30(5):1443-1466. http://dx.doi.org/ 10.1016/j.jbankfin.2005.03.022

Fei, Lanfang. 2009. "Enforcement of Arbitral Awards Between Hong Kong and Mainland China: A Successful Model?" Chinese Journal of International Law 8(3):621-636. http:// dx.doi.org/10.1093/chinesejil/jmp019

Fier, Andreas. 1998. Politik und wirtschaft am ende der DDR und in den neuen bundesländern, In H. Bertram, W. Kreher, I. Müller-Hartmann (Eds.), Systemwechsel zwischen projekt und prozess, Analysen zu den umbrüchen in Ostdeutschland: 21-52, KSPW: Transformationsprozesse Bd. 13, Opladen.

Fier, Andreas, and Michael Woywode. 1994. Unternehmensgründungen im ostdeutschen transformationsprozess, in: $Z E W$ Wirtschaftsanalysen: 237-260. Bd. No. 3, Baden-Baden.

Flaherty, Martin S. 2013. "Hong Kong Fifteen Years after the handover: One Country, Which Direction?" Columbia Journal of Transnational Law 51:275-286.

Fung, Anthony Y.H. 2007. "Political Economy of Hong Kong Media: Producing a Hegemonic Voice." Asian Journal of Communication 17(2): 159-171. http://dx.doi.org/10 1080/01292980701306530

Gong, Xinyi. 2011. "When Hong Kong Becomes SAR, Is the Mainland Ready? Problems of Judgments Recognition in Cross-Border Insolvency Matters." International Insolvency Review 20(1):57-73. http://dx.doi.org/10 1002/iir.186

Grabher, Gernot, and David Stark. 1997. "Organizing Diversity: Evolutionary Theory, Network Analysis, and Post-Socialism." Pp. 1-31 in Restructuring Networks in Post-Socialism, edited by G. Grabher, and D. Stark. New York: Oxford University Press.

Hannan, Michael T., and John Freeman. 1989. Organizational Ecology. Cambridge: Harvard University Press. 
Hanson, Norwood R. 1961. Patterns of Discovery. Cambridge: Cambridge University Press.

Henisz, Witold J., and Andrew Delios. 2001. "Uncertainty, Imitation, and Plant Location: Japanese Multinational Corporations, 19901996." Administrative Science Quarterly 46(3):443-75. http://dx.doi.org/10.2307/ 3094871

Holliday, Ian, Ma Ngok, and Ray Yep. 2004. "After 1997: The Dialectics of Hong Kong Dependence." Journal of Contemporary Asia 34(2):254-270. http://dx.doi.org/10 1080/00472330480000081

Hong Kong Special Administrative Region. Various Years. Companies Registry. Hong Kong.

Hung, Ho-fung. 2010. "Uncertainty in the Enclave." New Left Review, 66:55-77. http: //dx.doi.org/10.1177/0920203X10382710

Hung, Ho-fung, and H. Kuo. 2010. "One Country, Two Systems' and its Antagonists in Tibet and Taiwan." China Information 24(3):317337.

Jones, Eric I. 1981. The European Miracle. New York: Cambridge University Press.

Knight, Frank 1921. Risk, Uncertainty, and Profit. Boston: Houghton Mifflin Co.

Kraar, Louis. 1995. "The Death of Hong Kong." Fortune, June 26, 1995.

Ingram, Paul, and Tal Simons. 2000. "State Formation, Ideological Competition, and the Ecology of Israeli Workers' Cooperatives, 1920-1992." Administrative Science Quarterly 45(1): 25-53. http://dx.doi.org/10.2307/ 2666978

Kuilman, Jeroen G., and J.T. Li. 2006. "The Organizers' Ecology: An Empirical Study of Foreign Banks in Shanghai." Organization Science 17(3):385-401. http://dx.doi.org/ 10.1287 /orsc. 1060.0182

Lawrence, D. 2005. Setting Up a Business in Hong Kong. Hong Kong: Deacons.

Lui, Tai-lok. 1999. "Hong Kong Society: Anxiety in the Post-1997 Days." Journal of Contemporary China 8(20):89-101. http://dx.doi org/10.1080/10670569908724337

Martin, Michael F. 2007. Hong Kong: Ten Years After the handover. CRS Report for Congress. Washington, DC.
Michelman, Frank I. 1967. "Property, Utility and Fairness: Comments on the Ethical Foundations of 'Just Compensation' Law." Harvard Law Review 80(6):1165-1257. http: //dx.doi.org/10.2307/1339276

North, Douglas. 1992. "Institutions and Economic Theory." American Economist, 36(1):36.

Oksanen, Kaisa. 2011. "Framing the Democracy Debate in Hong Kong." Journal of Contemporary China 20(70): 479-497. http://dx.doi org/10.1080/10670564.2011.565179

Olson, Mancur. 2000. Power and Prosperity. Oxford: Oxford University Press.

Palmisano, Samuel. 2014. Re-Think: A Path to the Future. New York: Center for Global Enterprise.

Pan, Zhongdang Chin-chuen Lee, Joseph M. Chan and Clement Y.K. So. 1999. "One Event, Three Stories: Media Narratives of the handover of Hong Kong in Cultural China." International Communication Gazette 61: 99112.

Pegg, J. 1998. "Emigration Fall 'Sign of Confidence'; Mass Return from 'Greener Pastures."' South China Morning Post, December 30, 1998.

Qing, Cao. 2000. "Journalism as Politics: Reporting Hong Kong's handover in the Chinese Press. Journalism Studies 1(4):665-678. http://dx.doi.org/10.1080/ 146167000441367

Raynor L. 1990. "The Hong Kong Enigma." The Round Table: The Commonwealth Journal of International Affairs 79(313):39-42. http:// dx.doi .org/10.1080/00358539008453966

Rubenstein, Daniel. 1997. "Legal and Institutional Uncertainties in the Domestic Contract Law of the People's Republic of China." McGill Law Journal 42:495-536.

Salaff, Janet, Angela Shik, and Arent Greve. 2008. "Like Sons and Daughters of Hong Kong: The Return of the Young Generation." China Review 8(1):31-57. Sharma, Yojana. 1996. "Hong Kong Outlook: Cautious Optimism as handover Nears." South China Morning Post, December 23, 1996.

Silk, Leonard. 1987. "Hong Kong's Uneasy Boom." New York Times, July 24, 1987, p. 2. 
Simon, Herbert A. 1968. "On Judging the Plausibility of Theories." Pp. 439-458 in Logic, Methodology and Philosophy of Sciences. Vol. 3, edited by B. van Rootselaar and J. Staal Amsterdam: North Holland

Simons, Tal, and Paul Ingram. 2003. "Enemies of the State: Interdependence between Institutional Forms and the Ecology of the Kibbutz, 1910-1997." Administrative Science Quarterly 48(4):592-621. http://dx.doi.org/10 $2307 / 3556638$

Sing, Ming. 2001. "The Problem of Legitimacy for the Post-handover Hong Kong Government." International Journal of Public Administration 24(9):847-867. http://dx.doi org/10.1081/PAD-100104776

Singapore Government. Various Years. Statistics Singapore. Singapore.

Skocpol, T. 1979. States and Social Revolutions. Cambridge: Cambridge University Press. http://dx.doi.org/10.1017/ CB09780511815805

So, Alvin Y. 2000. "Hong Kong's Problematic Democratic Transition: Power Dependency or Business Hegemony?" Journal of Asian Studies 59(2): 359-381. http://dx.doi.org/ $10.2307 / 2658660$

Spenner, Kenneth I., Olga O. Suhomlinova, Sten A. Thore, Kenneth C. Land, and Derek C. Jones. 1998. "Strong Legacies and Weak Markets: Bulgarian State-Owned Enterprises during Early Transition." American Sociological Review 63(4):599-617. http://dx.doi.org/ $10.2307 / 2657270$

Stark, David. 1996. "Recombinant Property in East European Capitalism." American Journal of Sociology 101(4):993-1027. http: //dx.doi.org/10.1086/230786

Stinchcombe, Arthur L. 1965. "Social Structure and Organizations." Pp.142-193 in Handbook of Organizations, edited by J. March. Chicago: Rand McNally.

Tsay, Ruey S. 2005. Analysis of Financial Time Series. New York: Wiley. http://dx.doi org/10.1002/0471746193

Tukey, John. 1977. Exploratory Data Analysis. Reading, MA: Addison-Wesley.

Vickers, Simon. 2001. "More Colonial Again? The Post-1997 Culture of Hong Kong's Gov- erning Elite." International Journal of Public Administration 24(9):951-975. http://dx doi.org/10.1081/PAD-100104781

Weingast, Barry. 1995. "The Economic Role of Political Institutions: Market-Preserving Federalism and Economic Development." Journal of Law, Economics and Organization 11(1): $1-31$.

Weingast, Barry. 1997. "Federalism as a Commitment to Preserving Market Incentives." Journal of Economic Perspectives 11(4):83-92. http://dx.doi.org/10.1257/jep.11.4.83

Williamson, Oliver E. 1996. The Mechanisms of Governance. New York: Oxford University Press.

Windzio, Michael. 2003. Organisation, Strukturwandel und Arbeitsmarktmobilität. Wiesbaden: Westdeutscher Verlag. http://dx doi .org/10.1007/978-3-322-87349-1

Yeung, Iris, and Nelson Chiu. 2000. "An Outlier Analysis of the Hong Kong Stock Market Index." Applied Economics Letters 7(8):531-534. http://dx.doi.org/10.1080/ 13504850050033328

Acknowledgements: We appreciate the financial support of the Graduate School of Business, Stanford University. Lihua Wang, Olav Sorenson, Johannes Pennings, and Zilin He provided comments on earlier drafts.

Glenn R. Carroll: Stanford University. E-mail: gcarroll@stanford.edu.

Mi Feng: Peking University. E-mail: fengmi@gmail.com.

Jeroen G. Kuilman: Tilburg University. E-mail: j.g.kuilman@tilburguniversity.edu. 